\title{
Doporučení pro diagnostiku a léčbu ischemické choroby dolních končetin
}

Doporučené postupy vycházejí ze soudobých poznatků lékařské vědy a považují se za postupy lege artis. Jedná se však o doporučení, nikoli předpisy, proto je nutný individuální přístup u každého nemocného. Ošetřující lékař může použít jiný postup, musí však v dokumentaci rádně zdůvodnit, proč se od doporučeného postupu odchýlil.

Miroslav Bulvas

Oddělení intervenční angiologie, III. interní klinika, Fakultní nemocnice Královské Vinohrady a 3. lékařská fakulta Univerzity Karlovy, Praha, Česká republika

Tato doporučení nepostihují problematiku cévních onemocnění v celém rozsahu. Mohou posloužit jako obecné vodítko při hledání správných preventivních, diagnostických a léčebných postupů. Kromě obecných principů se v př́istupu k nemocnému a jeho léčbě stále více uplatňují individuální hlediska.

Striktně vzato, jsou jako periferní arteriální onemocnění označována ta, která postihují tepny mimo srdce. Jedná se tedy o pojem značně široký, zahrnující aortu, přívodné tepny a množství regionálních cirkulací. Někdy se ze skupiny periferních arterií vyčleňují i tepny vyživující mozek. Jindy je pojem periferní arteriální onemocnění používán pro postižení tepen zásobujících končetiny, a to hlavně končetiny dolní.

Nejčastějším onemocněním periferních tepen bývá ve více než $90 \%$ prípadů ateroskleróza či aterotrombóza, jejichž následkem dochází k omezení krevní dodávky do tkání, periferně od místa hemodynamicky významného postižení. Vzácnější je výskyt vaskulitid, aneurysmat, embolií, traumatu či útlaku tepny. Arterie horních končetin jsou postiženy zrrídka. $\mathrm{V}$ dalším textu se zaměříme na postižení tepen zásobujících dolní končetiny.

Podle rychlosti vzniku příznaků a průběhu onemocnění v čase rozlišujeme akutní (subakutní) a chronické stavy, které lze dále rozdělit do řady stadií. Z hlediska prognostického, léčebného, sociálního i ekonomického jsou nejzávažnější př́pady s akutními uzávěry tepen dolních končetin a chronickou kritickou ischemií.

\section{Epidemiologie}

Ateroskleróza je generalizované onemocnění, kterého přibývá s věkem. Nemocní s asymptomatickým postižením periferních tepen a ti, kteří mají pouze mírnou symptomatiku (klaudikace), jsou ohroženi hlavně následky koronární nemoci a postižení karotických tepen, případně tepen ledvinných a aorty.

Specifické rizikové faktory aterosklerotického postižení periferních tepen nejsou prokázány a uplatňují se zde stejná rizika, jako u tepen $\mathrm{v}$ jiných lokalitách. Jsou to hlavně věk, pohlaví, kouření, diabetes mellitus, hypertenze, hypercholesterolemie, hyperhomocysteinemie a zvýšená koncentrace C-reaktivního proteinu.

Kouření zvyšuje riziko vzniku ischemické choroby dolních končetin (ICHDK) 2-6krát a toto riziko se zvyšuje s počtem vykouřených cigaret. ${ }^{(1)}$ Potencuje účinek jiných rizikových faktorů a uplatňuje se výrazněji při postižení tepen dolních končetin než při vzniku koronární nemoci. ${ }^{(2)}$ Je to jediný rizikový faktor, který lze definitivně odstranit. U bývalých kuřáků bylo prokázáno snížení výskytu klaudikací ve srovnání s kuřáky.

Diabetes mellitus je dalším důležitým faktorem, který zvyšuje riziko vzniku postižení končetinových tepen. Nekontrolovaný diabetes vede $\mathrm{k}$ dyslipidemii, charakterizované vysokou koncentrací triglyceridů, LDL-cholesterolu a snížením HDL-cholesterolu. Hlavním problémem je inzulinová rezistence a s ní spojené nahromadění rizikových faktorů (porucha metabolismu lipidů, hypertenze, obezita). Není jasné, zda kontrola diabetu ovlivní výskyt makrovaskulárních změn, nicméně snižuje výskyt neuropatie a infekčních komplikací. U inzulin dependentního diabetes mellitus vede zlepšení kontroly hyperglykemie ke zpomalení progrese diabetické mikroangiopatie. U diabetiků, kteři jsou na dietě, byla nalezena negativní korelace mezi koncentrací lipoproteinů o vysoké denzitě a výskytem oblite-

Adresa: doc. MUDr. Miroslav Bulvas, CSc., Oddělení intervenční angiologie, III. interní klinika, FNKV a 3. LF UK, Šrobárova 50, 10034 Praha 10, Česká republika, e-mail: mbulv@fnkv.cz 
rující aterosklerózy. Se zhoršující se kontrolou diabetu a délkou jeho trvání se zvyšuje pravděpodobnost postižení tepen vyživujících dolní končetiny. Riziko vzniku postižení tepen dolních končetin se u diabetiků zvyšuje 2-4krát. ${ }^{(3,4)}$ Mnohem výraznější je zde riziko vzniku chronické kritické ischemie a významných amputací (5-15krát). Kromě cévního postižení se na horší prognóze podílejí i diabetická neuropatie a snížená rezistence $\mathrm{k}$ infekci.

V oblasti poruchy metabolismu lipidů se za významné riziko považuje zvýšení celkového a LDL-cholesterolu, hypertriglyceridemie a pokles koncentrace HDL-cholesterolu. ${ }^{(5)}$ Vzestup celkového cholesterolu nalačno $>7 \mathrm{mmol} / \mathrm{l}$ zdvojnásobuje riziko vzniku intermitentní klaudikace. Role triglyceridů není jednoznačná a některé studie jejich význam pro rozvoj ICHDK neprokazují.

Arteriální hypertenze je rizikovým faktorem, jehož význam pro vznik postižení koronárního či cerebrovaskulárního řečiště je vyšší než pro periferní tepny. Při vzniku intermitentních klaudikací se vliv hypertenze uplatňuje více u žen než u mužů. Obecně však má menší význam než diabetes a kouření.

Hyperhomocysteinemie zvyšuje riziko aterosklerózy 2-3krát a mechanismus jejího účinku není jasný. ${ }^{(6)}$ Pozitivní vliv snížení koncentrace homocysteinu nebyl zatím prokázán.

C-reaktivní protein je sérologický ukazatel zánětu a jeho zvýšená koncentrace se častěji nachází u pacientů s postižením tepen dolních končetin, ${ }^{(7)}$ zvláště u závažnějších klinických forem.

Přítomnost a závažnost perfuzní poruchy nezávisejí pouze na onemocnění samotných cév, ale i na některých protrombotických a prokoagulačních krevních odchylkách. Nemocní s ICHDK mají častěji zvýšený hematokrit, fibrinogen a krevní viskozitu. Tyto změny jsou často dávány do souvislosti s kouřením.

Výskyt onemocnění tepen dolních končetin výrazně stoupá s věkem, je vyšší u černé rasy ve srovnání s bílou, ${ }^{(8)}$ o něco vyšší je frekvence u mužů ve srovnání s ženami, zvláště v mladších věkových kategoriích.

Význam rizikových faktorů je prokazován nejen při vzniku aterosklerózy a aterotrombózy, ale i symptomatickém postižení (intermitentní klaudikace) a progresi onemocnění. Kromě uvedených ukazatelů signalizuje zvýšené riziko progrese u nemocných s intermitentní klaudikací i nízký dopplerovský index kotník-paže $(<0,5)$ a systolické distální tlaky $(<40-60 \mathrm{~mm} \mathrm{Hg})$.

Prevalence postižení periferních tepen narůstá a progrese onemocnění se urychluje s počtem přítomných rizikových faktorů. Protektivní účinek má mírná konzumace alkoholu.

Přítomnost symptomatického či asymptomatického postižení tepen dolních končetin je sama o sobě rizikovým faktorem, zvyšujícím pravděpodobnost vzniku cévní mozkové prŕhody, infarktu myokardu a kardiovaskulární smrti, a to zvláště při nízkém tlakovém indexu kotník-paže či lokalizaci postižení do oblasti arteriální trifurkace pod kolenem. Dopplerovský tlakový index kotník-paže (ABI, AAI) se tak stal důležitým markerem pro stanovení úrovně rizika úmrtí z jakékoli př́ičiny, i rizika úmrtí na kardiovaskulární onemocnění. ${ }^{(9)}$ Pravděpodobnost úmrtí se v obou případech zvyšuje nejen s poklesem $A B I$, ale is jeho vzestupem nad 1,4 . To souvisí se změnami tepen vedoucími $\mathrm{k}$ jejich zvýšené rigiditě.

Zanechání kouření a léčba hyperlipidemie mají pozitivní vliv u nemocných s aterosklerózou.

Prevalence onemocnění periferních tepen v populaci závisí na kritériích použitých k diagnóze.

Intermitentní klaudikace se u lidí kolem 60. roku věku nacházejí v 1-6 \%, 1,5-2krát častěji u mužů. Prevalence klaudikace se může zvýšit od 40leté do 70leté populace z 3,1 \% na 7,7 \%. ${ }^{(10)}$ Využitím neinvazivního vyšetření bylo zjištěno, že mezi 40 a 75 lety se prevalence periferního tepenného postižení mění z $2,4 \%$ na $22 \%$ !

Také incidence klaudikace stoupá $s$ věkem ${ }^{(11)}$ a mění se i s pohlavím. U mužů od 35-74 let stoupá incidence klaudikace (na 10000 osob) z 6 na 61, u žen ze 3 na 54. U žen bývá incidence 2-3krát nižší, $\mathrm{k}$ mužům se přibližuje po 65. roce věku. U mladších nemocných (< 40 let) je klaudikace způsobena častěji postižením aortoilického segmentu, zatímco u starších klaudikantů bývá častěji postižen segment femoropopliteální.

Přibližně 2/3-3/4 klaudikantů zůstanou stabilizováni. U 1/3-1/4 pacientů se obtíže časem zhorší a $<$ než $10 \%$ bude vyžadovat amputaci. ${ }^{(12,13)}$ Kouření, diabetes, hyperlipidemie, hypertenze a prrítomnost postižení cév periferie dolních končetin jsou považovány za významné rizikové faktory pro přechod nemoci z klaudikačního stadia do stadií závažnějších. Kritická ischemie vznikne přibližně u $1 \%$ mužů starších 55 let.

U diabetiků je minimálně pětkrát vyšší riziko pro vznik kritické ischemie než u nediabetiků. ${ }^{(14)}$ Nemocní s diabetes mellitus 2. typu mají 20krát častěji postiženy končetinové tepny ve srovnání s odpovídající nediabetickou populací a častěji mají postiženy tepny v oblasti pod kolenem. ${ }^{(15)}$ Riziko amputace končetiny je u diabetiků 10-20krát vyšší oproti nediabetikům. V souvislosti s diabetickou neuropatií vnímají nemocní bolest omezeně a s opakovanou, ložiskovou traumatizací se vyvinou nehojící se vředy. Není-li přítomna významná porucha perfuze, dojde $\mathrm{k}$ vyhojení vředů při odstranění traumatu. Vředy a gangrény se vyskytují asi u 10 \% diabetiků starších věkových skupin. Existují tři hlavní faktory, které vedou ke vzniku nekróz a ulcerací na nohách diabetiků (diabetická noha) - neuropatie, ischemie a infekce.

Počet nemocných, kterým je ročně amputována končetina, se odhaduje na 300 z 1 milionu obyvatel. V České republice je to tedy přibližně 3000 netraumatických amputací ročně.

Kardiovaskulární mortalita je u nemocných s onemocněním periferních tepen zvýšena. U více než $50 \%$ z nich se vyskytuje koronární nemoc a zvýšený je i výskyt cerebrovaskulárního postižení. Třetina nemocných s klaudikacemi vykazuje změny na EKG při zátěži a u více než $10 \%$ lze koronarograficky prokázat postižení tří tepen. ${ }^{(16)}$ Některé údaje ukazují na $17 \%$ výskyt významného koronárního 
postižení u pacientů s ICHDK, kteří mají hodnoty dopplerovského tlakového indexu vyšší než 0,75 , zatímco tam, kde je uvedený index nižší než 0,25 , se významná koronární nemoc nachází ve $33 \%$ př́padů. U nemocných s multisegmentálním postižením tepen, zásobujících dolní končetiny, je výskyt angiograficky významné koronární nemoci přibližně dvojnásobný. U klaudikantů kolísá mortalita v pětiletém období mezi $20-40 \%$. V prrítomnosti významného koronárního postižení se uvedené hodnoty zvyšují. Koronární prŕhody jsou u klaudikujících mužů dvakrát častější a u žen dokonce pětkrát častější než je tomu u zdravé populace. Koronární nemoc je zodpovědna za $63 \%$ úmrtí u klaudikantů. Dalších 7-17 \% zemře na mozkovou př́hodu.

Zatímco klaudikační stadium se uplatňuje hlavně zhoršením kvality života, progrese do stadia kritické ischemie představuje nejen ohrožení končetiny, ale i samotného života. Přibližně $60 \%$ nemocných s kritickou ischemií je léčeno chirurgicky nebo intervenčně, $20 \%$ prodělá primární amputaci a $20 \%$ je léčeno konzervativně.

Za rok po stanovení diagnózy chronické kritické ischemie dolních končetin prodělá $25 \%$ nemocných amputaci nad kolenem, $20 \%$ zemře a $55 \%$ bude žít s oběma končetinami. ${ }^{(17)}$ Jiné údaje ukazují, že 50 \% nemocných s klidovými bolestmi zemře do pěti let. Vysoká mortalita je způsobena generalizací aterosklerózy a příčinou smrti bývá obvykle infarkt myokardu či cévní mozková př́hoda. ${ }^{(18)} \mathrm{S}$ amputací se prognóza těchto pacientů dále zhoršuje. Perioperativní mortalita amputací pod kolenem je udávána $\mathrm{v}$ rozmezí 5-10 \% a pro amputace nad kolenem 15-20\%. Do dvou let po amputaci zemře $25-30 \%$ nemocných a po pěti letech nežije 50-75\% nemocných.

Při akutní ischemii dolních končetin závisí osud končetiny i nemocného na rozsahu i době trvání ischemie, úspěšnosti léčby (obnovení krevní dodávky) a na výskytu závažných komplikací. Z hlediska dlouhodobého účinku léčby má význam individuální objasnění prř́čin, které vedly $\mathrm{k}$ tepennému uzávěru a jejich odstranění. Na 1 milion obyvatel je ročně akutním periferním tepenným uzávěrem postiženo přibližně 500 osob; 60-70 \% těchto nemocných jsou starší než 65 let a 1,5-2krát častěji jsou postiženi muži než ženy.

\section{Zásady diagnostiky}

Při diagnostice postižení končetinových tepen využíváme anamnestických údajů, fyzikálního vyšetření a řady pomocných metod. S jejich využitím stanovujeme, zda je tepenné poškození přítomno, které úseky řečiště jsou postiženy, a určujeme stadium nemoci. Klinický stav a výsledky vyšetření rozhodnou o léčebném postupu.

Akutní ischemie končetinových tepen je charakterizována náhlým vznikem obtíží u nemocného, který do té doby neměl problémy, či náhlým zhoršením symptomatiky (doba trvání akutních příznaků do 1-2 týdnů). Chronickou formu lze charakterizovat přítomností kolaterálního oběhu (angiografie), jehož účinnost může být různá. Časově hovoříme o chronicitě onemocnění, trvají-li příznaky déle než tř́i měsíce. Nemocní s chronickou formou ischemické choroby končetin sice vědí, kdy obtíže začaly, ale $\mathrm{z}$ různých důvodů nebyli v té době léčeni.

Trvání příznaků mezi 8. dnem a koncem třetího měsíce označujeme jako subakutní období.

Při anamnéze věnujeme pozornost přítomnosti rizikových faktorů, intermitentních klaudikací, klidových ischemických bolestí, vývoji funkčního omezení, trofických změn a prodělané chirurgické či katetrizační terapii. Podle lokalizace klaudikací soudíme na to, které úseky tepenného systému jsou postiženy. Bolesti v plantě signalizují postižení tepen bérce a nohy. Jsou-li lokalizovány v lýtku, lze soudit na postižení femoropopliteálního segmentu. Povrchová stehenní tepna má ve svém stehenním průběhu funkci transportní, zatímco tkáně stehna jsou vyživovány převážně hlubokou stehenní tepnou. Proto stehenní klaudikace signalizují poruchu průtoku hlubokou stehenní tepnou. Její izolované postižení je však raritou a myslíme na něj při anamnéze stehenních klaudikací a při přítomnosti arteriálních pulsací v periferii končetiny. Příčinou sníženého průtoku touto tepnou bývá většinou významná stenóza či uzávěr v oblasti zevní či společné pánevní tepny. Za této situace však také vázne přítok do povrchové stehenní tepny. Klaudikační obtíže se proto lokalizují jak do oblasti stehna, tak i do lýtka. Intenzita námahových svalových bolestí a pořadí jejich nástupu $\mathrm{v}$ obou uvedených oblastech kolísá. Při uzávěru aortoilického úseku se dostavuje bolest v hýždích (porucha průtoku skrze arteria iliaca interna) obvykle spojena se slabostí a únavností i distálnějších svalových skupin.

Klidové ischemické bolesti jsou téměř vždy lokalizovány v oblasti nohy a přicházejí a zhoršují se v noci, vleže. Při svěšení končetiny či po postavení, se jejich intenzita zmenšuje či dokonce vymizí.

Dnes nejčastěji používanou funkční klasifikaci chronické formy ischemické choroby dolních končetin představili v roce 1954 Fontaine a spol. ${ }^{(19)}$ Rozděluje nemocné do čtyř stadií (tabulka 1).

$\mathrm{Z}$ terapeuticko-indikačních důvodů se II. stadium dále rozděluje na stadium II a (s klaudikačním intervalem nad 200 m, relativně dobrá kompenzace) a II b (<200 m chůze, špatná kompenzace).

Jiná klasifikace zahrnuje více objektivních, neintervenčních kritérií a umožňuje lépe standardizovat léčebné postupy $^{(20,21)}$ (tabulka 2).

$\mathrm{Na}$ rozdíl od klaudikačního stadia, kdy vázne perfuze svalových skupin pouze při zátěži, klidové ischemické bolesti signalizují závažnou poruchu prokrvení, kdy tkáňové požadavky na dodávku živin a kyslíku nejsou zabezpečeny

\begin{tabular}{ll} 
Tabulka 1 & Funkční klasifikace chronické formy ICHDK podle \\
Fontaina & \\
\hline I. & Stadium klinicky latentního postižení tepen \\
\hline II. & Klaudikační stadium, klidové bolesti nejsou prítomny \\
\hline III. & Stadium klidových ischemických bolestí \\
\hline IV. & Stadium trofických ulcerací a gangrén \\
\hline
\end{tabular}


ani v klidu. I drobné trauma může v této situaci navodit vznik hlubokých tkáňových defektů. Stav, kdy vázne klidový krevní průtok natolik, že končetina je ohrožena, označujeme jako kritickou ischemii. Vznikem kritické ischemie se zásadním způsobem zhoršuje prognóza.

Chronická kritická ischemie dolních končetin je definována každým ze dvou následujících kritérií.

Je to prrítomnost klidové ischemické bolesti, která vyžaduje analgetickou léčbu po dobu delší než dva týdny s kotníkovým systolickým tlakem 50 mm Hg či méně a/nebo tlakem na palci $\leq 30 \mathrm{~mm} \mathrm{Hg}$.

Druhým kritériem je př́tomnost ulcerací či gangrén na noze či prstech s kotníkovým systolickým tlakem $\leq 50 \mathrm{~mm}$ $\mathrm{Hg}$ či tlakem na palci $\leq 30 \mathrm{~mm} \mathrm{Hg}$, popř. s transkutánním tlakem kyslíku $\left(\mathrm{TcO}_{2}\right) \leq 10 \mathrm{~mm} \mathrm{Hg} \mathrm{v}$ postižené oblasti. ${ }^{(22)}$ Ve Fontainově klasifikaci odpovídá chronické kritické ischemii stadium III. a IV.

Akutní ischemie dolních končetin je charakterizována náhlým vznikem perfuzní poruchy či zhoršením chronické hypoperfuze. Mírnější postižení se projevuje vznikem či zhoršením klaudikací. Příznakem signalizujícím akutní ohrožení končetiny je vznik klidové bolesti a senzorimotorické dysfunkce. Tehdy je v sázce nejen končetina, ale i život nemocného. Embolizace do zdravé tepny mívá dramatičtější symptomatiku než trombóza v tepně s chronickým zúžením a rozvinutým kolaterálním oběhem.

Méně častou formou akutní ischemie je ischemické postižení akrálních částí - syndrom modrého prstu ("blue toe syndrome"), způsobený mikroembolizací ze zdroje umístěného proximálně (nitrosrdeční trombóza, aneurysma, nepravidelná stenóza tepny, popliteální „entrapment“). Samotné postižení prstů pacienta obvykle neohrožuje, avšak jeho prognóza je významně ovlivněna příčinným onemocněním a možností i rizikem jeho eliminace. Mortalita spojená se syndromem modrého prstu se pohybuje mezi 0-20\% a amputace jsou popisovány v 0-32\% prrípadech. ${ }^{(23)}$

Při fyzikálním vyšetření si všímáme barvy kůže, její teploty, trofických změn a prrítomnosti otoku a náplně po- vrchových žil nohy, přítomnosti interdigitální mykózy. Stav srovnáváme se zdravou či méně postiženou končetinou. Spolu s poklesem kožního průtoku může být končetina v akrálních partiích bledá až cyanotická (stáza). Kožní teplota klesá, u chronických stavů bývá přítomna atrofie kưže a jejích adnex (snížené ochlupení, změny na nehtech a jejich zpomalený růst). Atrofují i hypoperfundované svaly, což se může projevit zmenšením obvodu stehna či lýtka v porovnání se zdravou končetinou. Palpačně pak zjištujeme změnu jejich konsistence, kdy se stávají měkčí. Nekrózy se tvoří nejčastěji na prstech a patě. Zánětlivé komplikace se mohou šírit až na kostní tkáň, otok a zčervenání okolí defektu mohou signalizovat porušení žilní a lymfatické drenáže. Jizvy a jejich umístění nám napoví, jaké revaskularizační operace pacient prodělal.

Vyšetřením přítomnosti a kvality arteriálních pulsací lokalizujeme místo uzávěru, případně aneurysmatické rozšíření.

Šelest nad tepnami signalizuje přítomnost turbulence, obvykle v souvislosti se sklerotickým postižením, zužujícím lumen. Šelesty nad pánevními tepnami a v tř́slech se mohou manifestovat až po několika dřepech (zvýšení kardiálního výdeje a urychlení krevního proudu). Dlouhé, systolicko-diastolické šelesty jsou přítomny při AV zkratech, krátké (systolické) při hyperkinetické cirkulaci.

Fyzikální vyšetření pohledem se uplatňuje i při polohovém testu, který se provádí vleže. Pozorováním plosek a prstů při klidové elevaci končetin můžeme odhalit postupující blednutí kůže. Nemocný pak provádí plantární a dorsální flexe, vždy ve vteřinových intervalech, a to maximálně po dobu dvou minut. Hodnotíme dobu cvičení, příčinu jeho ukončení a lokalizaci bolestí, které se při cvičení objeví. Nemocný se pak posadí a nohy rychle svěsí. Pro obě končetiny měříme dobu vzniku prvního zčervenání (normálně do 5 vteřin), difuzního zčervenání kůže na celé noze (do 15 vteřin) a čas žilní náplně (do 10 vteřin). Př́itomnost skvrnité hyperemie svědčí pro postižení drobných kožních arterií. Časy žilní náplně nelze hodnotit u nemoc-

Tabulka 2 Funkční klasifikace ICHDK podle objektivních kritérií

\begin{tabular}{|c|c|c|c|}
\hline Stupeň & Kategorie & Klinický popis & Objektivní kritéria \\
\hline \multirow[t]{4}{*}{ I } & 0 & Asymptomatické postižení & Normální zátěžový test - treadmill \\
\hline & 1 & Mírné klaudikace & $\begin{array}{l}\text { Dokončený zátěžový test } \\
\text { - pozátěžový DT je > } 50 \mathrm{~mm} \text { Hg a o více než } 25 \mathrm{~mm} \text { Hg pod normál }\end{array}$ \\
\hline & 2 & Střední klaudikace & Symptomy mezi kategoriemi 1 a 3 \\
\hline & 3 & Těžké klaudikace & $\begin{array}{l}\text { Nedokončený zátěžový test } \\
\text { - pozátěžový DT je < } 50 \text { mm Hg }\end{array}$ \\
\hline II & 4 & Klidové ischemické bolesti & $\begin{array}{l}\text { Klidový DT je } \leq 40 \text { mm Hg } \\
\text { - plethysmografický kotníkový či metatarzální záznam pulsů je zploštělý, } \\
\text { tlak na palci je }<30 \mathrm{~mm} \mathrm{Hg}\end{array}$ \\
\hline \multirow[t]{2}{*}{ III } & 5 & $\begin{array}{l}\text { Malá ztráta tkáně, nehojící se vřed, } \\
\text { fokální gangréna s difuzní ischemií nohy }\end{array}$ & $\begin{array}{l}\text { Klidový DT je } \leq 60 \mathrm{~mm} \mathrm{Hg} \\
\text { - zploštělý plethysmografický záznam, tlak na palci je }<40 \mathrm{~mm} \mathrm{Hg}\end{array}$ \\
\hline & 6 & $\begin{array}{l}\text { Velká ztráta tkáně, šírící se nad transmetatarzální } \\
\text { úroveň, funkční nohu nelze zachránit }\end{array}$ & Stejně jako pro kategorii 5 \\
\hline
\end{tabular}


ných s insuficiencí povrchních žil (varixy), kdy se krev vrací retrográdně. Těžká porucha perfuze se projevuje prodloužením času žilní náplně přes 35 vteřin. Pravidelně vyšetřujeme polohový test při ambulantních kontrolách a sledujeme případnou progresi onemocnění. Jednoduše tak můžeme např. posoudit, zda subjektivní pocity zhoršení odpovídají i zhoršení časů polohového testu. $\mathrm{V}$ průběhu hospitalizace využíváme polohového testu k hodnocení účinku léčby.

Pro stanovení př́tomnosti uzávěru či významné stenózy tepen je třeba, aby alespoň dva $\mathrm{z}$ následujících ukazatelů byly přítomny - klaudikace, nepřítomnost arteriálních pulsací při fyzikálním vyšetření a pozitivní polohový test. Senzitivita takto provedené diagnostiky je $100 \%$ a specificita $80 \% .^{(24,25)}$

U akutních uzávěrů se uplatní posuzování aktivní hybnosti a kožní senzitivity. Jejich omezení či úplné vymizení signalizuje ohrožení končetiny (tabulka 3).

Stupeň II se někdy rozděluje ještě podle klinické naléhavosti na podtyp II A, kde k revaskularizaci musí dojít během dnů až týdnů, a na podtyp II B, kde musí být reperfuzní terapie zahájena během několika hodin.

Vzhledem k tomu, že chirurgická léčba pomocí Fogartyho balonkové embolektomie je u embolizace výrazně úspěšnější, než je tomu u trombózy, pokoušíme se odhadnout, jakého původu akutní uzávěr je. Zdrojem embolů bývá ve většině případů srdce (90\%), a tak pátráme po srdečních onemocněních (arytmie, kardiomyopatie, revmatická choroba srdeční, aneurysmata apod.). To, že dojde k uzávěru tepen na více místech (např. horní i dolní končetina, cerebrovaskulární insuficience) ve stejnou dobu, ukazuje na embolický původ uzávěru. Přítomnost klaudikací $\mathrm{v}$ anamnéze, ještě v době před známkami akutního uzávěru, svědčí pro spoluúčast chronického postižení tepen dolních končetin, a tedy pro možnost trombózy. Cestující embolus má tendenci uvíznout v místě tepenných bifurkací (aortální, femorální, tibioperoneální) a/nebo se zde rozdělí na části, které uvíznou v dceřiných větvích. $\mathrm{V}$ diferenciální diagnostice embolie - trombóza tak může pomoci i angiografie.

\section{Vyšetřovací metody}

Neinvazivní vyšetřovací metody představují důležitý doplněk při určení klinické diagnózy. S jejich pomocí stanovujeme řadu fyziologických a hemodynamických parametrů,

\begin{tabular}{|c|c|c|c|}
\hline Stupeň & $\begin{array}{l}\text { Klinická } \\
\text { klasifikace }\end{array}$ & $\begin{array}{l}\text { Senzorimotorické } \\
\text { funkce }\end{array}$ & $\begin{array}{l}\text { Distální dopplerovský } \\
\text { signál (arterie/žíla) }\end{array}$ \\
\hline I. & $\begin{array}{l}\text { Viabilní } \\
\text { končetina }\end{array}$ & Intaktní & $(+/+)$ \\
\hline II. & $\begin{array}{l}\text { Ohrožená } \\
\text { končetina }\end{array}$ & Oslabeny & $(-/+)$ \\
\hline III. & $\begin{array}{l}\text { Ireverzibilně } \\
\text { poškozená } \\
\text { končetina }\end{array}$ & Chybí zcela & $(-/-)$ \\
\hline
\end{tabular}

jejichž znalost umožňuje posoudit dopad organického či funkčního postižení cévního řečiště na cirkulaci krve $\mathrm{v}$ dolních končetinách.

Získané údaje se uplatňují při zjištování, zda je cirkulační porucha př́tomna, a jak je významná. Lze je korelovat s anamnestickými údaji, a provádět tak objektivizaci obtíží, mohou stanovit oblast nejzávažnější anatomické poruchy, předurčovat a verifikovat výsledky léčby, ovlivnit volbu léčebné metody. Ultrasonografie může podat informace i o anatomických změnách.

Mezi hlavní výhody neinvazivních vyšetření patří jejich dostupnost, nebolestivé provádění, téměř nulové riziko poškození nemocného, relativně nízká cena, a jsou také zdrojem fyziologických informací, které nelze invazivními zobrazovacími metodami běžně získat. $\mathrm{V}$ zásadě bychom neměli provádět diagnostické intervenční vyšetření, když požadované informace lze obdržet neinvazivně. Některé z technik jsou využívány běžně (např. dopplerovské vyšetření distálních tlaků), jiné se provádějí pří výzkumné práci.

Analýza krevních vzorků se neuplatní při diagnóze končetinové ischemie, ale má význam v detekci a kontrole některých rizikových faktorů aterotrombózy, popř. komplikací. Rutinně stanovujeme krevní obraz včetně počtu trombocytů, glykemii nalačno a glykemický profil, koncentraci fibrinogenu, kreatininu, $\mathrm{N}$ urey, ionty, krevní lipidy, homocystein, krevní sedimentaci, C-reaktivní protein, koagulační testy. $Z$ dalších vyšetření se pravidelně uplatňuje EKG, sonografické vyšetření karotických tepen (každých 6-12 měsíců), břišní aorty, popř. další podle přidružených onemocnění. U akutní končetinové ischemie se může uplatnit stanovení kreatinkinázy a myoglobinu v krvi (moči).

\section{Měření krevního tlaku}

Krevní tlak v tepnách dolních končetin je parametrem, který je nejčastěji sledován neinvazivními metodami. Jeho snížení signalizuje přítomnost tokové překážky, např. stenózy či uzávěru; průkaz existence tlakového gradientu má tady diagnostický význam. Se stoupajícím hemodynamickým významem tokové překážky vzrůstá i tlakový gradient (rozdíl tlaku nad překážkou i pod ní)) a perfuzní porucha. Stanovení hodnoty krevního tlaku je relativně jednoduché a jejím měřením v různých arteriálních segmentech končetiny lze zjistit, v které oblasti je toková překážka hemodynamicky nejvýznamnější. Naměřené hodnoty porovnáváme s tlakem $\mathrm{v}$ oblastech, kde předpokládáme normální poměry (horní končetiny, kontralaterální dolní končetina). Podobně lze stanovit tlakové rozdíly mezi jednotlivými arteriálními segmenty postižené končetiny. ${ }^{(26)}$ Klasická poslechová metoda měření krevního tlaku, založená na Korotkovových fenoménech, se na dolních končetinách uplatňuje obtížně, nebot akustické projevy lze uchem těžko spolehlivě zachytit.

\section{Sphygmomanometrie}

Tento způsob měření krevního tlaku je založen na detekci projevů krevního proudění distálně od tlakové manžety 
obepínající končetinu. Zvýšením tlaku v manžetě nad hodnotu systolického tlaku obvykle docílíme zástavu krevního proudu díky zevní kompresi tepen. Nezdaří se nám to však tehdy, když tepny pod manžetou vykazují zvýšenou rigiditu díky patologickým strukturálním změnám (diabetes mellitus, Moenckebergova kalcinóza, chronická dialýza). Kontrolovaným poklesem tlaku vzduchu v manžetě docílíme toho, že v okamžiku dosažení hodnoty systolického tlaku se známky proudění v periferii končetiny opět objeví. Je tedy zřejmé, že s pomocí sphygmomanometrie jsme schopni stanovit pouze hodnotu systolického krevního tlaku. V oblasti končetinových tepen to však diagnostické využití nesnižuje narozdíl od hodnocení cirkulace centrální.

$\mathrm{K}$ detekci krevního proudění se využívají různé typy senzorů, i když sphygmomanometrický princip metody se nemění.

Nejstarší metodou nepřímého měření krevního tlaku je metoda palpační, kde se hodnota systolického tlaku stanoví v okamžiku pohmatové detekce arteriálních pulsací periferně od tlakové manžety. Dnes se obvykle využívá k zachycení krevního proudění různých typů plethysmografických metod, ultrazvuku a spektroskopie. ${ }^{(27)}$ Oproti palpační metodě tak lze detekovat přítomnost arteriálních pulsací a krevního proudění (a tedy i měřit systolický tlak) i tehdy, je-li amplituda pulsových vln nízká a pohmatem je nelze zachytit.

K chybám při měření tlaku může docházet v souvislosti $s$ použitím příliš úzké tlakové manžety. Doporučovány jsou šíře $15,5 \mathrm{~cm}$ pro manžetu umístěnou na stehně, nad kolenem a pod ním, $13 \mathrm{~cm}$ při poloze nad kotníky a dva $\mathrm{cm}$ při umístění na palci.

Také rychlý pokles tlaku v manžetě (přes $5 \mathrm{~mm} \mathrm{Hg/s}$ ) se může odrazit v naměření tlaku nižšího, než odpovídá skutečnosti. Platí to zvláště u osob s pomalejší tepovou frekvencí.

Význam má i teplota okolního prostředí. Je-li nízká, může vést $\mathrm{k}$ vasokonstrikci a ke snížení tlaku v periferii.

Zvýšení rigidity cévní stěny vede obecně ke zvýšení hodnoty systolického tlaku (změna pružníkové funkce). Tento stav znemožňuje také dostatečnou kompresi tepen tlakovou manžetou, a tak vede $\mathrm{k}$ naměření enormně vysokých tlaků i v oblastech kritické ischemie. ${ }^{(28,29)}$ Při měření prstových tlaků se podobně může uplatnit i zvýšená tuhost kůže v počátečních fázích sklerodermie, kdy ještě nejsou př́tomny arteriální obstrukce.

Důležitá je i správná funkce manometru. Při použití rtutového tlakoměru dbáme na jeho umístění ve výši srdce, podobně umístěna má být i končetina (poloha vleže). Skleněný sloupec se rtutí má být ve svislé poloze a v klidu dosahuje rtut výše označení nulového tlaku.

Tlaková manžeta musí být obtočena tak, aby dobře přiléhala. Je-li příliš volná, naměříme tlaky vyšší, než jsou ve skutečnosti. Důvodem je posunutí nafukované elastické části manžety a její vyboulení mimo zevní neelastický látkový kryt. Situace se pak podobá použití úzké manžety.

Detekce krevního proudění má být prováděna co nejblíž $\mathrm{k}$ tlakové manžetě. Obecně sice platí, že měříme hodnoty tlaku v oblasti, kde je umístěna tlaková manžeta, ale jen tehdy, když mezi umístěným detekčním senzorem a manžetou nejsou významné překážky toku. ${ }^{(30)}$ Proto např́iklad při umístění manžety na stehno přikládáme dopplerovskou sondu nad podkolenní tepnu. Kdybychom prováděli detekci nad arteria tibialis posterior či arteria dorsalis pedis, mohli bychom naměřit nižší tlaky při významném postižení tepen mezi manžetou a kotníkem.

\section{Plethysmografie}

Plethysmografie zahrnuje řadu metod, s jejichž pomocí lze zaznamenat změnu objemu. Obecně vzato se měřicí systém skládá z jednotky zachycující i signalizující změnu objemu a měniče, který zachycený signál upravuje tak, aby mohl být zaznamenán. Součástí je i záznamové zařízení, popř. monitor.

K rychlé změně objemu končetiny může dojít jedině v souvislosti se změnou objemu krve, a tak lze pomocí plethysmografie zaznamenávat každou pulsovou vlnu a také arteriální klidový či maximální průtok sledovanou oblastí. K měření průtoku využíváme krátkodobé komprese žil tlakovou manžetou, čímž blokujeme odtok krve z končetiny či některého jejího segmentu. Končetina pak nabývá na objemu v souvislosti s arteriálním přítokem.

Detekce rychlého poklesu objemu se uplatní při posuzování poruch žilní drenáže (žilní vyprazdňování).

Plethysmografie má řadu metodických variant, které se liší podle typu používaného senzoru.

\section{Vodní plethysmografie}

Jedná se o nejstarší a pravděpodobně i o nejspolehlivější techniku na měření objemu. Sledovaná část končetiny je uzavřena v komůrce naplněné tekutinou. Velikost objemu, o který se končetina zvětší, odpovídá objemu tekutiny, která je $\mathrm{z}$ komůrky vytlačena. Tímto způsobem lze dobře měřit objemy (krevní průtoky) nohy (distálně od kotníků) nebo prstů. Protože v těchto místech relativně malé množství krevního průtoku připadá na svalovou a kostní tkáň, naměřené změny objemu nás informují o perfuzi kůže.

Při měření objemových změn v oblasti bérce je obtížné a časově náročné dobře utěsnit vodní komůrku na dvou místech (pod kolenem a nad kotníky). Proto je výhodnější používat vodní manžety, kterými obtočíme sledovanou část končetiny podobně jako při měření tlaku. ${ }^{(31)}$ Změny objemu bérce se pak projeví vzestupem tlaku v manžetě, který můžeme po kalibraci systému převádět prrímo na jednotky objemu. Vzhledem k tomu, že na bérci či stehně je zastoupena hlavně tkáň svalová, týkají se naměřené hodnoty svalového průtoku.

\section{Vzduchová plethysmografie}

Ve srovnání s plethysmografí́ vodní je zde nahrazena voda vzduchem. ${ }^{(32)}$ Důvodem bylo omezit problémy s únikem vody z měřicího systému. Jedná se o jednoduchou techniku, při které se využívá tenkostěnných vzduchových manžet, přiložených na různá místa končetiny. Zvětšením objemu tkáně se zvyšuje tlak vzduchu v manžetě, což je změřeno tlakoměrem a po převedení na elektrický proud zapsáno. 
Cirkumferenční tenzometrická plethysmografie („strain gauge plethysmography”)

Při této metodě se na končetinu přikládá př́ččně po obvodu tenká pružná hadička naplněná rtutí a na koncích hadičky jsou umístěny elektrické svody (můstek podle Whitneyho). ${ }^{(33)}$ Zvětšuje-li končetina $v$ místě měření svůj objem (a tedy i obvod), hadička se protahuje, sloupec rtuti se prodlužuje a jeho elektrická rezistence se zvyšuje. Změny rezistence jsou počítačem převáděny na hodnoty průtoku krve stanovené na mililitr tkáně. Chyby v měření mohou nastat, je-li objem sledované tkáně malý (prsty) nebo není-li příčný průřez končetiny $\mathrm{v}$ místě sledování kruhový (např. př̀i měření na nártu). Relativní změny se však i zde zachytí spolehlivě.

\section{Impendanční plethysmografie (IPG)}

Krev vykazuje menší elektrickou rezistenci než všechny ostatní tkáně končetiny. Proto se stoupajícím objemem krve v sledované oblasti klesá elektrický odpor tkáně. Prakticky se provádí tak, že na končetinu se umístí dvě obvodové elektrody, mezi kterými probíhá stř́ídavý proud. Do tkáně v oblasti mezi uvedenými elektrodami jsou umístěny dvě elektrody senzorické a monitorují se rozdíly napětí mezi nimi při tkání probíhajícím stř́ídavém proudu. Pokles tkáňové rezistence lze zaznamenat s každou přicházející pulsovou vlnou.

Některé úvahy se v minulosti opíraly o představu, že elektrická rezistence tkáně se primárně mění s kardiálním výdejem - průtokem (rheokardiografie, rheografie). Změny elektrického odporu tkáně však odrážejí velikost pulsového objemu a jeho změny nemusejí kopírovat kardiální výdej.

\section{Fotoplethysmografie (PPG)}

Fotoplethysmografie je založena na principu prosvícení zkoumané tkáně, jehož intenzita kolísá s množstvím krve obsažené ve tkáni. Světelný zdroj prosvětluje tkáň a na jiném místě je přiložen fotoelektrický senzor, který hodnotí intenzitu pronikajícího světla. ${ }^{(34)}$ Při transmisivní fotoplethysmografii je tkáň umístěna mezi světelný zdroj a fotosenzor (konečky prstů, ušní lalůček). Reflexní fotoplethysmografie využívá hodnocení světla ze tkáně odraženého. V tomto př́padě jsou světelný zdroj i senzor umístěny vedle sebe.

Metoda se používá hlavně pro hodnocení změn pulsového objemu v kưži. Problémem pro interindividuální hodnocení jsou rozdíly v barvě a tlouštce kưže. Fotoplethysmografie je metodou hojně využívanou a oblíbenou pro svou jednoduchost a dostupnost.

Protože řada okolností může ovlivnit kožní průtok na periferii končetin ještě před měřením, je nutné vyšetřovat za stálé a dostatečné okolní teploty, dvě hodiny před vyšetřením nejíst a nekouřit a vyvarovat se emočních stimulů.

\section{Segmentální plethysmografie}

Některé typy senzorů (vodní či vzduchové manžety, rtutové můstky) lze na končetině umístit v sérii, a tak hodnotit objemové a tlakové změny $\mathrm{v}$ řadě arteriálních segmentů. Při využití kalibrace lze objemové změny i kvantifikovat.
Tímto zpo̊sobem můžeme blíže identifikovat oblast s hemodynamicky významnými překážkami toku. Vyšetření lze prakticky kombinovat s dopplerovským stanovením segmentálních tlaků, kdy stejné manžety připojíme $\mathrm{k}$ plethysmografu a zaznamenáváme křivky pulsového objemu.

Předchůdcem segmentální plethysmografie byla oscilografie. Paralelně na obou končetinách byly na zvolených oblastech uloženy vzduchové manžety. Arteriální pulsace zvyšovaly tlak v manžetách a tato zvýšení byla zapisována jako oscilace, jejichž amplituda se hodnotila. Zapisovaly se vedle sebe oscilace ze dvou manžet najednou, a tak bylo možno porovnávat výši oscilací v odpovídajících oblastech obou končetin i jejich případný pokles v manžetě umístěné periferněji. ${ }^{(35,36)}$ Záznamy oscilací bylo možno provádět i po zátěži či za chladových testů. Snížení amplitudy signalizovalo prítomnost tepenného postižení.

\section{Vyšetření ultrazvukem}

Nejjednodušším využitím ultrazvukového vyšetření je měření distálních, systolických tlaků a stanovení tlakového indexu „kotník-paže“ (AAI = ankle-arm index; ABI = ankle-brachial index; ABPI = ankle-brachial pressure index) pomocí malých dopplerovských př́strojů, které vysílají ultrazvuk kontinuálně („CW doppler“). Ultrazvukový signál vysílaný do tkáně je odrážen od pohybujících se erytrocytů a poté je opět zachycen a převeden do slyšitelné formy, př́padně zaznamenán. Odchylka frekvence vracejícího se signálu (oproti vysílanému) se mění s rychlostí pohybu erytrocytů. Kromě přítomnosti proudění krve a jeho rychlosti můžeme hodnotit i směr toku (ve směru sondy či proti sondě).

Měření distálních tlaků má význam diagnostický, nebot' jejich pokles signalizuje přítomnost překážky v tepenném řečišti, někdy umožňuje postižení lokalizovat a určit stupeň poruchy. Nejčastěji postupujeme tak, že dopplerovskou sondou detekujeme přítomnost pulsatorního proudění $\mathrm{v}$ arteria dorsalis pedis a arteria tibialis posterior za vnitřním kotníkem. Tlakovou manžetu umístujeme nad kotníky. Systolický tlak na horní končetině můžeme stanovit klasickou poslechovou metodou nebo pomocí dopplerovské sondy, umístěné nad a. radialis či a. brachialis, s tlakovou manžetou na předloktí či paži.

Systolický tlakový gradient vzniklý přes konstantní tepennou překážku stoupá s krevním tlakem centrálně od překážky. Systolický tlak za překážkou se tedy nezvyšuje lineárně se systolickým tlakem před překážkou. Dopplerovský tlakový index „kotník-paže“ (poměr kotníkového systolického tlaku k systolickému tlaku na paži) je méně závislý na změnách tlaku před stenózou či uzávěrem. Obvyklé hodnoty tohoto indexu u zdravých osob jsou 1,0-1,1. Za patologické jsou považovány hodnoty $<0,9$ a $>1,3$. Pozitivní nález $(\mathrm{ABI}<0,9)$ svědčí pro prrítomnost tokové překážky od tlakové manžety směrem $\mathrm{k}$ srdci, a vyšetření tak slouží jako screening, při kterém není arteriální stenóza či uzávěr přesněji lokalizována. Pouze když zjistíme rozdílné hodnoty systolického tlaku při vyšetřovací sondě nad a. tibialis posterior a a. dorsalis pedis, znamená to, že 
zadní a přední bércová tepna mají různou průchodnost nebo odlišný stupeň kolateralizace. Pro toto měření lze obvykle využít běžné tlakové manžety, nebot rozměry distálního bérce odpovídají poměrům na paži.

Tepny se zvýšenou rigiditou jsou obtížně komprimovatelné a hodnoty tlaku nelze s pomocí tlakové manžety správně změřit. $\mathrm{V}$ takových případech naměříme kotníkové tlaky enormně vysoké $(A B I>1,3)$ i při kritické ischemii. V takových prrípadech si pomáháme stanovením tlaku na palci dolní končetiny za použití prstových tlakových manžet. Hodnota prstového tlaku je normálně asi o $30 \mathrm{~mm}$ Hg nižší než kotníkový tlak a za snížený tlakový index prsty-paže (TBI) považujeme hodnotu $<0,7$. Detekci pulsací zde lze jednoduše provést fotoplethysmograficky.

Pro hodnocení viability ischemické dolní končetiny má však stanovení absolutní hodnoty distálního tlaku význam větší než tlakový index „kotník-paže.“ U 77 \% dolních končetin $s$ angiograficky ověřeným postižením tepen a se zjištěným kotníkovým systolickým tlakem < 60 mm Hg byla nutná intervence či amputace. Naopak u 86 \% končetin s tlakem $>60 \mathrm{~mm} \mathrm{Hg}$ nebyla prováděna amputace ani intervence $\mathrm{k}$ záchraně. ${ }^{(37)}$

Stanovení tlakového indexu a kotníkových tlaků po námaze může odhalit poruchu, která se v klidu neuplatňuje.

Pro stanovení segmentálních tlaků ${ }^{(38)}$ přikládáme tlakové manžety na horní stehno, oblast nad kolenem a pod ním, nad kotníkem a na palec. Rozdíl mezi tlaky sousedních segmentů, který činí $\geq 20 \mathrm{~mm} \mathrm{Hg}$, je považován za signifikantní. Za významný rozdíl tlakového indexu mezi segmenty považujeme hodnotu 0,1 . Měření tlaku na různých částech dolní končetiny umožňuje lokalizovat oblast, ve které se překážka nachází i posoudit, zda je postižení izolované nebo mnohočetné (další intersegmentální gradienty).

Tepny dolních končetin mohou být podrobeny komplexnímu vyšetřování složitějšími ultrazvukovými systémy, podobně jako arterie $\mathrm{v}$ řadě dalších oblastí. To nám umožňuje získat černobílý obraz anatomie (B-mode) v okolí cév i uvnitř (tromby, ateromy, stenty), barevný obraz (color flow) krevního proudění uvnitř cév (podobné angiografii) a zobrazit rychlostní charakteristiky proudění v čase („spectral Doppler“). Nevýhodou je, že podrobné vyšetření tepen dolních končetin je časově náročné a může trvat déle než angiografické vyšetření s okamžitou endovaskulární léčbou. Mezi limitacemi se uvádějí - př́ítomnost střevního plynu při vyšetření pánevního řečiště a aorty, tortuózní průběh tepen, kalcifikace, obezita, edém okolní tkáně, zpomalení krevního proudění za proximálními uzávěry. V současnosti se diagnostická duplexní sonografie tepen dolních končetin, ve srovnání s vyšetřením žilního systému, uplatňuje méně. Využívá se však velmi dobře při sledování nemocných po angiochirurgických či endovaskulárních léčebných výkonech. Vyšetření se soustředuje na intervenovanou oblast a upozorňuje na nutnost včasné reintervence.

\section{Kožní termometrie}

Teplota kůže je dobrým ukazatelem její perfuze. Naměřená teplotní hodnota je však ovlivněna řadou fyzikálních i fy- ziologických faktorů. Patří k nim teplota, vlhkost a proudění vzduchu ve vyšetřovací místnosti, úroveň metabolické, nervové, vasomotorické a sudomotorické aktivity, vliv nikotinu a přijmu potravy. Je obtížné všechny uvedené faktory udržet $\mathrm{v}$ rovnováze, a tedy měření absolutní hodnoty kožní teploty není standardně v diagnostice používáno. ${ }^{(27)}$ Větši smysl má tedy určování teplotních topografických gradientů (sledování tepelných rozdílů mezi vybranými kožními oblastmi) nebo temporálních gradientů (rozdíl teploty v čase) při dynamických kožních testech. Vztahy mezi krevním průtokem a kožní teplotou jsou nelineární a do teploty $28^{\circ} \mathrm{C}$ relativně nízký vzestup průtoku výrazně zvyšuje teplotu kůže. Naopak, nad touto hodnotou je při daném vzestupu průtoku př́růstek teploty relativně malý.

Obvykle je teplota kůže měřena přímo, pomocí přiloženého termického senzoru. Senzory mohou být na bázi termo-elektrických článků, kde vzniká při spojení dvou různých kovů elektrický potenciál, a jeho výše je závislá na teplotě. Odlišné jsou termistory, složené ze slitin kovů, u kterých dochází k výraznému posunu elektrické rezistence při změně teploty.

V závislosti na teplotě vyzařuje kůže infračervené záření, které lze detekovat, zaznamenávat infrakamerou a sledovanou oblast barevně mapovat (termografie). Barvy se liší podle teploty, a tak lze rychle stanovit isotermální linii (oblasti se stejnou teplotou) nebo topografické a temporální gradienty.

Ve formě sprejů či nalepovacích pásek se využívá i tekutých krystalů, jejichž optické vlastnosti se mění s teplotou.

K posuzování kožní perfuze lze využít i měření tepelné vodivosti tkáně. Ta závisí na složení kůže (u daných jedinců konstantní) a na krevním průtoku. Tímto zpơsobem nelze získat absolutní hodnoty průtoku, ale stanovují se relativní změny.

\section{Transkutánní oxymetrie}

Jedná se o metodu zjištující úroveň oxygenace krve, která je založena na změnách absorpce barev. Deoxygenovaná krev absorbuje více barvy červeného spektra, zatímco oxygenovaná krev absorbuje více světla infračerveného. Oxymetr, obvykle umístěny na prst či ušní lalůček, vysílá i přijímá červené a infračervené světlo a z poměru přijatého červeného a infračerveného světla odvozuje parciální tlak kyslíku (norma $\mathrm{TcO}_{2}=50-75 \mathrm{~mm} \mathrm{Hg}$ ). Hodnotu lze snímat jako křivku měnící se s každým pulsem a periodickým přítokem okysličené krve. $\mathrm{V}$ praxi používáme dva detektory - jeden na hrudi (kontrolní) a druhý přesunujeme po jednotlivých segmentech končetiny. Pokles $\mathrm{TcO}_{2}<20 \mathrm{~mm} \mathrm{Hg}$ ukazuje na nízkou pravděpodobnost zhojení po amputaci. ${ }^{(39)}$

\section{Laserové dopplerovské vyšetření}

Vyšetřování kožní cirkulace je vzhledem ke komplexní anatomii složitější, nežli je tomu při vyšetřování transportní tepny o relativně velkém průměru.

I když existuje jistá variabilita, lze najít určité společné rysy ve složení kůže v různých lokalitách. Epidermis, zevní 
vrstva kůže, je avaskulární. Z papilárního arteriálního plexu, kde arterioly směřují paralelně s povrchem kůže, odstupují zásobující kapiláry kolmo, směrem k povrchu. Zde vytvářejí smyčky a vracejí se do subpapilárního žilního plexu. Arteriovenózní anastomózy se uplatňují v termoregulaci. Při jejich dilataci se zvýší kožní průtok s tím, že krev obchází nutriční kapiláry.

Vyslaný signál se tedy odráží od sítě drobných cév, které vedou krev různými směry. Díky mikroskopickým rozměrům cév je nevhodné použít energetický paprsek nízké frekvence (dlouhé vlnové délky). Namísto ultrazvuku je proto využíváno monochromatického světelného zdroje (laser). Cesta světelného paprsku není jednoduchá, nebot’ při průchodu tkání směrem k cévám i nazpět dochází k jeho rozptylu. Ve vyšetřované oblasti se paprsek odráží od cévní sítě, kde jednotlivé cévy či jejich okrsky svým průběhem zaujímají různé úhly ve vztahu ke zdroji světla a navíc kvalita zpětného signálu závisí i na součinu počtu červených krvinek v dané oblasti a jejich průměrné rychlosti proudění („,blood cell flux“). Vyšetřením tedy nelze získat izolované údaje o rychlosti krevního toku či o velikosti průtoku. Hlavním využitím je sledování perfuzních změn po různých provokacích (chlad, okluze, léky, polohové změny apod.). Výhodou laser-dopplerovského vyšetřování kožní cirkulace je jeho jednoduchá klinická aplikace a neinvazivita.

\section{Fonoangiografie}

Za normálních hemodynamických podmínek jsou jediné zvuky, které nad periferními tepnami slyšíme, propagované srdeční ozvy nad karotickými tepnami. Přítomnost šelestu nad vyšetřovanou tepnou obvykle signalizuje existenci turbulentního proudění vznikajícího v srdci či v oblasti mezi srdcem a vyšetřovanou tepnou. Př́ičinou turbulence je většinou onemocnění arteriální stěny vedoucí ke zúžení lumen. Oproti posuzování samotným poslechem umožňuje zvukový záznam (z mikrofonu umístěného nad tepnou) detailnější určení charakteru, trvání a načasování šelestu. Při relativně malé stenóze dochází ke vzniku turbulence jen v období nejrychlejšího proudění a šelest prokazujeme ve střední části systoly. Jak stenózující tepenný proces nabývá na významu, zvyšuje se rychlost proudění v postiženém místě a turbulence trvá až do diastoly (šelest se prodlužuje). Fonoangiograficky lze posuzovat i přítomnost zvukových frekvencí, které jsou mimo oblast zachytitelnou lidským uchem. Kvalitativní fonoangiografie sleduje změny amplitudy v čase, zatímco kvantitativní fonoangiografie posuzuje vztahy amplitudy a frekvence.

\section{Vyšetření klaudikační vzdálenosti}

Stanovení klaudikační vzdálenosti nemá u klaudikujících pacientů význam diagnostický, ale slouží k posouzení funkčního stavu a účinku léčby. Objektivizuje údaje nemocného a umožňuje preciznější srovnávání stavu v čase. Hodnocení provádíme na běžícím pásu za standardních podmínek (rychlost 3,2 km/h, sklon $12 \%$ ) nebo za postupného zvyšování rychlosti či sklonu každé 2-3 minuty. Lze využít i chůzi podle metronomu (90-120 kroků/min) na známou vzdálenost. Stanovujeme ušlou vzdálenost do doby vzniku bolesti (iniciální či bezbolestná klaudikační vzdálenost) a maximální klaudikační vzdálenost (nemocný definitivně zastaví pro bolest). Tato maximální klaudikační vzdálenost je lépe reprodukovatelná. Test ukončíme i z jiných důvodů, např. pro dušnost, stenokardie, arytmie. Po skončení zátěže nemocného položíme a každé dvě minuty měříme dopplerovským vyšetřením kotníkové tlaky a tlak na paži, až do návratu ke klidovým hodnotám. Hodnotíme dobu chůze, symptomy a důvod zastavení, kotníkové tlaky před vyšetřením a po něm a dobu jejich návratu $\mathrm{k}$ hodnotám před vyšetřením.

\section{Magnetická rezonance (MR)}

MR angiografie (MRA) je metoda, při které se zobrazuje tok krve cévami v množství příčných řezů. Jejich postupným spojením a rekonstrukcí získáme obraz podobný angiografickému. Výhodou je, že zde není třeba používat klasické RTG kontrastní látky (jodované) s jejími vedlejšími účinky, a že není využíváno ionizačního záření. Mezi limitacemi MR se uvádějí tendence $\mathrm{k}$ nadhodnocování významnosti stenóz a nemožnost použití u nemocných s některými kovovými pomůckami v těle (např. defibrilátory, kochleární implantáty). Přítomnost kovových stentů negativně ovlivňuje obraz $z$ dané oblasti. Provádění vyšetření s použitím kontrastní látky (CE MRA) zlepšilo senzitivitu metody při diagnostice postižení periferních tepen, která se pohybuje mezi $71-100 \%,{ }^{(40)}$ specificita se udává mezi 5-100 \%. Bývají to hlavně tepny malého průměru (bércové, pedální), kde jsou výsledky méně přesné ve srovnání $s$ angiografií. Kontrastní látka používaná při MRA (na bázi gadolinia) sice nezpůsobuje renální insuficienci, ale u nemocných s tímto postižením se udává zvýšené riziko vzniku nefrogenní systémové fibrózy. Ve srovnání s CT angiografii se zde neuplatňuje ovlivnění obrazu artefakty z kalcifikací.

\section{CT angiografie (CTA)}

CT angiografie je semiinvazivní metoda, při které se RTG kontrastní látka vstřikuje do žíly na předloktí nebo do centrální žíly. Po průtoku kontrastu plicním řečištěm je jeho tok zachycen na sérii RTG záznamů příčných řezů. Počítačovým zpracováním jsou vytvářeny rekonstrukce $2 \mathrm{D}$ a 3D. Metoda umožňuje nejen posouzení lumen tepny, ale i její stěnu a přilehlé struktury (nástěnné tromby, edém, krvácení, kalcifikace). Problémem bývá zhoršená možnost hodnocení za přítomnosti kalcifikací ve stěně nebo kovového materiálu (stenty, spirály). Zobrazení bércových tepen má zatím ve srovnání s digitální angiografií nižší kvalitu. U tepen většího průměru se senzitivita i specificita metody udává přes $96 \%$. $^{(41)}$

\section{Digitální subtrakční angiografie (DSA)}

I přes technický pokrok a rozvoj ultrazvukové diagnostiky, MRA i CTA, zůstává angiografie standardní metodou k zobrazení tepen vyživujících dolní končetiny a ostatní zobrazovací metody jsou s ní srovnávány. Na rozdíl od mi- 
nulosti, kdy jako záznamové medium pro radiogram sloužil film, dnes využíváme digitální formy obrazu s možností počítačové úpravy, přenosu a záznamu. Po pořízení obrazu sledované oblasti se tento automaticky odečítá od dalšího záznamu s kontrastní látkou protékající cévou. Tím lze odfiltrovat pozadí a zlepšit vizualizaci kontrastu (snížit jeho koncentraci a celkovou dávku), zkrátit dobu vyšetření a omezit komplikace. Při přehledné angiografii zobrazujeme větší úseky cévního řečiště, např. břišní aortu s renálními tepnami, pánevní tepny a infrainguinální tepny. Selektivní nástřiky slouží k detailnějšímu zobrazení tepny v blízkosti angiografického katetru.

Angiografie je bezpečná metoda, která kromě informací o anatomii tepenného postižení přináší i některé dynamické poznatky. Absolutní kontraindikace tohoto vyšetření neexistují. Relativní kontraindikací je závažná hypertenze, koagulační porucha, alergie na kontrast, renální insuficience a kongestivní kardiální insuficience. $\mathrm{V}$ takových případech je třeba individuálně vážit prospěch s rizikem a provést opatření k jeho snížení. ${ }^{(42)}$ Komplikace se vyskytují vzácně a mohou být systémové, nebo se vážou k punkčnímu otvoru či k manipulaci s katetrem. Nejčastější komplikací, která se váže k přístupovému místu, je hematom. Malé hematomy jsou popisovány až v $10 \%$ případů; závažná krvácení vyžadující transfuzi či chirurgickou korekci se vyskytují do $0,5 \%$ při punkci v třísle (nejčastější přístup). Další komplikace (disekce, trombóza, pseudoaneurysma a AV píštěl, infekce) jsou také vzácné a dochází k nim v $1 \%$ prŕpadů. Systémové komplikace se vyskytují v $5 \%$, nejčastěji se jedná o zvracení, nauseu a vasovagální synkopu. Alergické projevy zahrnují vyrážku, svědění, otok víček, bronchiální spasmus a vyskytují se až ve $3 \%$ prrípadů.
Anafylaktická reakce při použití ionických kontrastů se udává v poměru 1 : 10000 až $1: 50000$ vyšetřených pacientů. ${ }^{(43)}$ Riziko rozvoje př́znaků z nefrotoxicity kontrastu je vyšší u nemocných s renální insuficiencí, inzulin dependentním diabetes mellitus, u dehydratovaných, a při aplikaci velkého množství kontrastu. Ke vzniku kontrastní nefropatie dochází u 1-6 \% vyšetřovaných. ${ }^{(44)}$ Při manipulaci s katetrem či vodičem může dojít $\mathrm{k}$ průniku do stěny tepny, $\mathrm{k}$ disekci či periferní embolizaci. K tomu dochází v méně než $0,5 \%$ výkonů.

Obecně vzato, angiografii provádíme obvykle tam, kde uvažujeme o angiochirurgické či intervenční léčbě k získání informací, které nelze opatřit jiným, méně invazivním způsobem. O indikaci i o způsobu provedení by měl rozhodnout klinicky erudovaný lékař, který ze symptomatiky, fyzikálního nálezu a výsledků pomocných vyšetření určí, kde je významné postižení lokalizováno (supra- či infrainguinálně). Je vhodné zvolit přístup tak, aby bylo možno př́padně provést endovaskulární léčbu v jedné době s diagnostickou angiografií.

Při indikaci angiografie u klaudikujících pacientů se řídíme jejich subjektivním pocitem významné limitace a snížení kvality života (obrázek 1). Současně posuzujeme přítomnost přidružených onemocnění, zda pro nemocného neznamenají vyšší ohrožení než ICHDK, a jaké představují riziko pro vyšetření a léčbu. Jednoznačně dáváme přednost intervenční léčbě, která má výsledky srovnatelné s chirurgickými postupy a výrazně nižší riziko. Může posouvat okamžik, kdy bude třeba léčby angiochirurgické. Při úvaze o intervenční terapii jsme benevolentnější oproti indikaci $\mathrm{k}$ chirurgickým výkonům a provádíme ji i u nemocných s klaudikačním intervalem delším než $200 \mathrm{~m}$. V praxi to

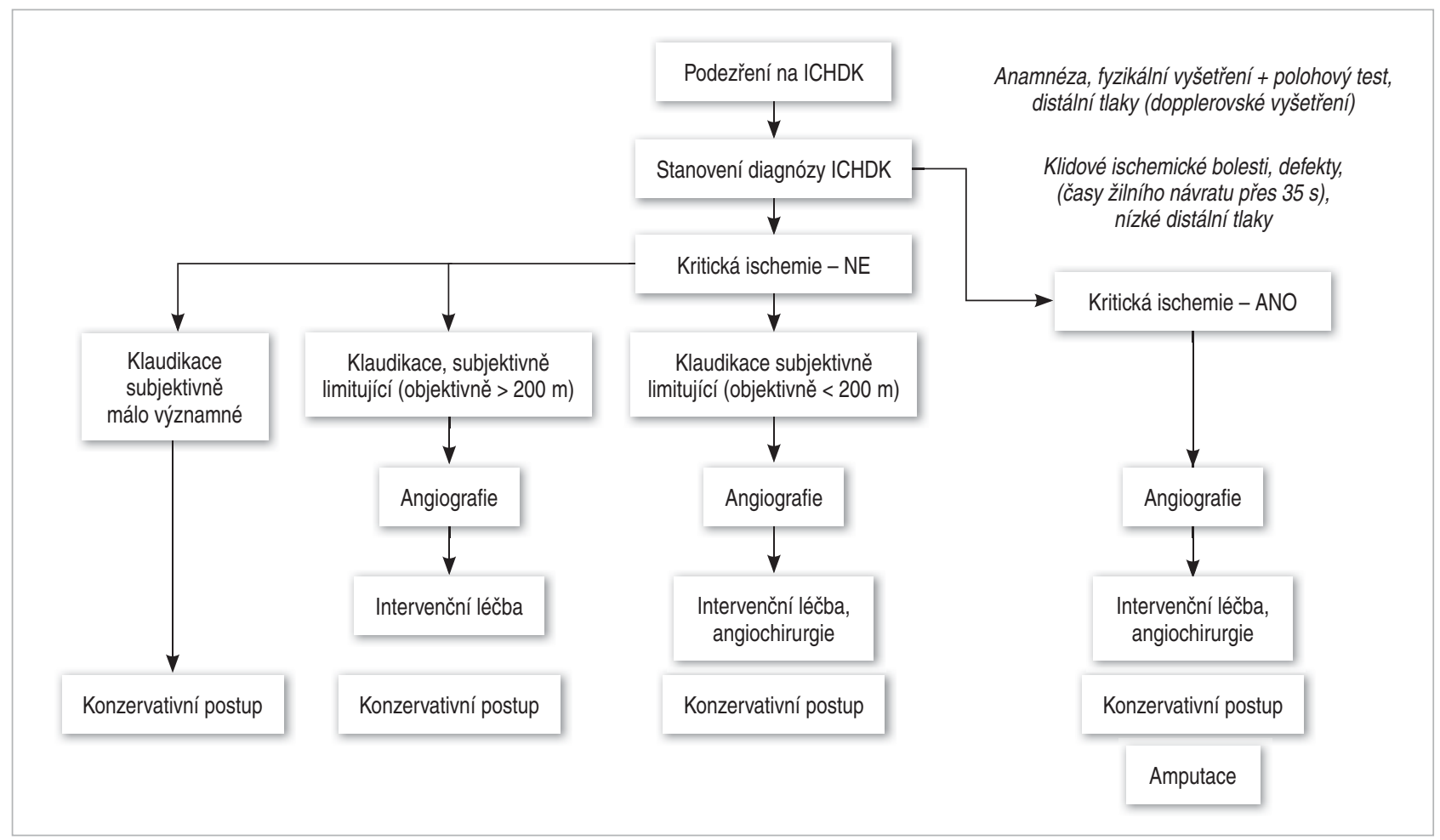

Obrázek 1 Schematické vodítko pro rozhodování o postupu u nemocných s chronickou formou ICHDK 
znamená, že u řady nemocných provádíme angiografii pouze k posouzení technické možnosti provedení intervenční terapie. Není-li možná, neznamená to automaticky, že pacient bude vzápětí operován.

U nemocných s ohroženou končetinou (chronická i akutní ischemie) musí být vyšetření provedeno co nejdříve, nebot' od výsledku se odvíjí možnost nekonzervativní terapie. Úspěšná nekonzervativní léčba znamená pro uvedené pacienty šanci na zlepšení jejich nedobré prognózy.

Při akutní ischemii končetiny je třeba postupovat tak, abychom mohli ze stejného prŕstupu pokračovat po angiografii v léčbě a vyvarovali se další arteriální punkci (riziko krvácení při trombolýze). Při infrainguinálním uzávěru (arteriální pulsace $\mathrm{v}$ třísle př́tomny) tedy provádíme ipsilaterální antegrádní punkci v třísle a po angiografii následuje zpravidla aspirační tromboembolektomie, lokální trombolýza či vzácněji jiný intervenční postup. Pod uzávěrem se nemusí periferní pahýl tepny plnit, i když není uzavřen (neprrítomnost kolaterálního oběhu). Z angiografického obrazu se tak lze domnívat, že je uzavřena i další periferie. V takové situaci není chirurgická léčba možná. Tehdy se po angiografii $\mathrm{z}$ antegrádního vpichu snažíme projít čerstvým uzávěrem a selektivním nástřikem pod ním prokázat, že a. poplitea či bércové tepny jsou volné (uzávěr je segmentální povahy).

Také při chronické formě onemocnění se snažíme provést angiografii ze vpichu, odkud bude možno provést ve stejné době i léčbu. U dlouhých uzávěrů povrchní stehenní tepny je třeba věnovat pozornost stavu arteria profunda femoris. Její významné postižení je třeba vyloučit vyšetřením v šikmé či laterální projekci, abychom nezanedbali možnost zlepšit kolaterální oběh obnovením toku krve touto tepnou.

Pokud je jedno tř́slo bez pulsací (uzávěr pánevní tepny či a. femoralis communis), provedeme ascendentní angiografii z katetru zavedeného nad aortální bifurkací z opačného třísla. O rekanalizaci postižené tepny se při příznivé anatomii postižení pokusíme $\mathrm{z}$ kontralaterální strany, přes aortální bifurkaci. Když se nám to nepodaří, provedená angiografie nám ozřejmí, zda je průchodná společná femorální tepna na postižené straně, a zda má smysl tuto tepnu punktovat a pokusit se o rekanalizaci z této strany.

Nejsou-li arteriální pulsace hmatné v obou tř́slech, zvážíme provedení MRA či CTA. I proto, že je zde vyšší pravděpodobnost primární chirurgické léčby.

$S$ angiografií může být spojeno i přímé měření krevního tlaku a tlakových gradientů při určování významnosti stenóz a hodnocení účinku léčby. Intravaskulární ultrazvukové vyšetření a angioskopie jsou metody, využívané hlavně při řešení výzkumných úkolů.

\section{Určení výšky amputace}

Správné stanovení výšky amputace má význam pro zhojení operační rány, mobilizaci nemocného, průběh rehabilitace a kvalitu života. Na hojení operační rány má vliv úroveň lokální perfuze, rozsah chirurgického traumatu, přítomnost hematomu a infekce.
Standardizované postupy pro určení výšky amputace neexistují a v řadě př́padů hraje roli zkušenost lékařuo. Při rozhodování je třeba vzít v úvahu rozsah gangrén a infekce, prrítomnost arteriálních pulsací proximálně od místa amputace. Využít lze i měření kožní teploty, která by měla být v místě amputace vyšší než $32^{\circ} \mathrm{C}$. Ve stejné oblasti bychom s pomocí stanovení segmentálních tlaků měli naměřit hodnoty > $60 \mathrm{~mm} \mathrm{Hg}$. Některá prcoviště se řídí úrovní kožního průtoku, kterou určují pomocí clearence intradermálně aplikovaných radioizotopů či fluorescenční technikou. Měřením $\mathrm{TcO}_{2}$ bylo prokázáno, že lepší šance na zhojení je při stanovení lokálních hodnot $>20 \mathrm{~mm} \mathrm{Hg}$. Význam má i angiografické vyšetření s průkazem př́mého zásobení až $\mathrm{k}$ úrovni amputace.

\section{Léčba ischemické choroby dolních končetin}

Mezi terapeutické postupy lze zahrnout snížení kardiovaskulárního rizika (sekundární prevence aterosklerózy), prevenci ztráty končetiny a prognosticky závažných kardiovaskulárních př́ihod, spolu se zlepšením kvality života. Léčebný př́stup k nemocnému je komplexní a potřebná opatření spočívají v opuštění kuřáckých návyků, ${ }^{(45)} \mathrm{v}$ kontrole diabetes mellitus a hypertenze, léčbě dyslipidemie, zavedení non-aterogenní diety, udržování správné tělesné hmotnosti a zvýšení fyzické aktivity. ${ }^{(46-56)}$ Mezi další obecná preventivní opatření patří podávání protidestičkových preparátů (antiagregancia) a inhibitorů ACE. Mortalita nemocných s ICHDK je ovlivněna hlavně přítomností poškození tepen koronárních, mozkových a aorty. Proto je třeba po těchto postiženích aktivně pátrat, i když jejich symptomatika může být zastíněna limitujícími obtížemi z poruchy perfuze dolních končetin.

Je mimo rozsah tohoto sdělení věnovat se detailně výše uvedeným opatřením a režimovým změnám, které zahrnují prevenci a detekci aterosklerózy i v jiných oblastech tepenného řečiště, a měly by být uplatňovány po zbytek života u všech nemocných.

Postupy zaměřené na zlepšení perfuze dolních končetin se liší podle symptomatiky, stupně a anatomie postižení, podle akutního či chronického průběhu a přítomnosti přidružených onemocnění.

\section{Zátěžová terapie}

Klaudikační stadium chronické ischemické choroby dolních končetin je charakterizováno arteriální insuficiencí při zátěži, což se klinicky projevuje vznikem křečovité bolesti postižených svalů. Funkční postižení spočívá v limitované toleranci zátěže a ve zkrácení vzdálenosti, kterou nemocný bez obtíží ujde. Dochází tak k omezení některých denních aktivit a ke zhoršení kvality života. Pacient není v této fázi ohrožen ztrátou končetiny.

Pravidelná aerobní zátěž zlepšuje klaudikační symptomatiku, což se vysvětluje intermitentním zvyšováním tlakového gradientu přes postižený úsek tepny, posílením vasodilatační funkce endotelu, redistribucí krevního toku, změnou metabolismu kosterního svalu, snížením krevní 
viskozity a zvýšením extrakce kyslíku. Kromě toho dochází k poklesu celkového cholesterolu a LDL-cholesterolu, systolického krevního tlaku a k prodloužení klaudikační vzdálenosti. ${ }^{(56)}$ Doba chůze a klaudikační vzdálenost se mohou po šesti měsících prodloužit přibližně třikrát (podobně jako po chirurgické léčbě).

Existuje řada zátěžových programů od těch, které pacient vykonává sám, po náročnější, probíhající pod kontrolou. Kontrolovaný zátěžový program je nejúčinnější. Měl by zahrnovat chůzi na běhátku (treadmill) takovou rychlostí, aby došlo k vyvolání mírných klaudikací do pěti minut. Po ústupu obtíží nemocný znovu pokračuje do mírného stupně bolesti a vše se opakuje. Takové cvičení má probíhat minimálně 30 minut a provádí se alespoň třikrát týdně po dobu 3-6 měsíců. ${ }^{(57)}$ Udržení dlouhodobé spolupráce ze strany pacienta bývá obtížné.

Jednodušším zátěžovým programem, při kterém se pacient kontroluje sám, je intervalový svalový trénink. Při něm se podle lokalizace tepenného uzávěru opakovaně krátce zatěžují různé svalové skupiny. Při tokové překážce v pánevních tepnách nemocný trénuje dřepy a při obstrukci femoro-popliteálního segmentu výstupy na špičky. Začíná otestováním své výkonnosti tak, že každou vteřinu provede jeden dřep nebo výstup na špičky až do vzniku bolesti a nutnosti cvičení zastavit (počet dřepů či výstupů počítá). Základem pro další cvičení jsou dvě třetiny ze zjištěného množství provedených cviků. $\mathrm{V}$ tomto dvoutřetinovém počtu provádí nemocný určené cviky tak, že po sérii úkonů odpočívá tři minuty vleže. Pak znovu cvičí a odpočívá. Po druhém odpočinku provádí stejný počet cviků potřetí. Tento celek, složený ze tří sérií cvičení, přerušovaných dvěma tř́minutovými přestávkami, se opakuje 2-3krát denně. Každý měsíc si nemocný provede sám přetestování maximálního počtu cviků. Zjistí-li zlepšení tolerance zátěže se zvýšením maximálního počtu, stanoví si nový dvoutřetinový počet, který se stane základem pro intervalový trénink.

Kromě některého ze zátěžových léčebných programů doporučíme pacientovi chodit co nejvíce, ale klaudikační bolest nepřemáhat (nebezpečí atrofie svalů). U nemocných s klidovými bolestmi nejsou zátěžové programy vhodné a při krátkých klaudikačních vzdálenostech mají malou či žádnou účinnost.

Před zahájením léčby a zvolením tréninkového programu je nutné provést vyšetření srdce, včetně zátěžového elektrokardiogramu.

\section{Farmakoterapie}

$\mathrm{V}$ minulosti byla podávána a testována řada preparátů s cílem prodloužit klaudikační vzdálenost. Historie je spojena hlavně s podáváním nejrůznějších léků s vasodilatačním účinkem (alkohol, reserpin, tolazolin, nitráty, isoproterenol, nifedipin, flunarizin, cinarizin, isoxsuprin a další). Jejich pozitivní účinek nebyl prokázán a uvažovalo se spíše o jejich vlivu na odčerpání krevního toku od ischemických oblastí (steal fenomén). Nicméně téměř všechny preparáty, u kterých bylo později prokázáno sta- tisticky významné prodloužení klaudikačního intervalu, mají, kromě jiného, i výrazný vasodilatační účinek.

Nejvíce důkazů pozitivního účinku bylo podáno pro inhibitor fosfodiesterázy 3 - cilostazol. Vykazuje aktivitu protidestičkovou, antitrombotickou, vasodilatační, dále zvýšení krevního průtoku, HDL-cholesterolu, pokles triglyceridů a inhibici buněk hladkého svalu cévní stěny. Průměrně bylo po jeho podání prokázáno prodloužení klaudikační vzdálenosti na treadmillu o $50-70$ m za 24 týdnů. $\mathrm{V}$ porovnávací studii s pentoxifylinem se prokázala větší účinnost cilostazolu. Lék je kontraindikován u nemocných s kongestivní kardiální insuficiencí.

Naftidrofuryl je antagonista 5-hydroxytryptamin-2 receptoru s vasodilatačním účinkem. Oproti placebu bylo po jeho podávání prokázáno průměrné prodloužení maximální klaudikační vzdálenosti o $71 \mathrm{~m}$.

Pentoxifylin je zařazován mezi hemoreologika pro svou schopnost zlepšovat deformabilitu červených i bílých krvinek, a zlepšovat tak možnost průniku přes kapiláry. Po jeho podání byl zjištěn i pokles koncentrace fibrinogenu a agregační aktivity trombocytů. Má silný vasodilatační účinek. Některé studie prokázaly, že po jeho podání došlo k prodloužení maximální klaudikační vzdálenosti o 44-48 m, ${ }^{(58-60)}$ jindy se uvádí, že jeho účinek je pouze marginální nebo žádný. Proto byl zařazen mezi léky s nedostatečným průkazem účinnosti u nemocných s intermitentní klaudikací. ${ }^{(56)}$

Kromě toho, že statiny snižují riziko vzniku či zhoršení klaudikací (simvastatin), bylo po jejich dlouhodobém podávání (atorvastatin, $80 \mathrm{mg}$ denně, 12 měsíců) prokázáno prodloužení klaudikační vzdálenosti o $63 \%$ ve srovnání s placebem, kde prodloužení činilo $38 \%{ }^{(61)}$ Podstata tohoto působení není objasněna, nejvíce se předpokládá pozitivní ovlivnění funkce endotelu.

Na symptomu intermitentní klaudikace se částečně také podílí změněný svalový metabolismus. Posílení oxidačního metabolismu tak může zlepšit funkci kosterního svalu i bez zvýšení krevního průtoku. L-karnitin a propionyl-L-karnitin slouží jako zdroj karnitinu pro Krebsův cyklus a mohou zlepšit oxidaci glukózy. Perorální podávání propionyl-L-karnitinu $\mathrm{v}$ dávce dvakrát denně $1 \mathrm{~g}$ zlepšilo klaudikační vzdálenost na treadmillu o 54-73\%.

Existuje celá řada dalších preparátů a technik, u kterých nebyl potřebný účinek na prodloužení klaudikační vzdálenosti spolehlivě prokázán, nebo studie s nimi probíhají. Naděje jsou vkládány do léčby pomocí angiogenních růstových faktorů a kmenových buněk podporujících tvorbu kolaterál.

V současnosti má farmakoterapie, cílená na prodloužení klaudikačního intervalu, pouze malý účinek, který zdaleka neodpovídá objemu předepisovaných léků. Nejspíše bychom ji doporučili u nemocných s krátkými klaudikacemi, u kterých není možná či vhodná chirurgická či intervenční léčba.

Farmakoterapie kritické končetinové ischemie je zaměřena na zhojení defektů, zabránění amputace či jejímu oddálení. Je důležitou součástí konzervativního postupu u nemocných, kde intervenční a chirurgická léčba není 
možná nebo nepřinesla potřebný pozitivní účinek. Cílem léčby je ovlivnit tři hlavní prríčiny progrese onemocnění. Jsou to: snížená perfuze, bakteriální tkáňová infekce a edém $\mathrm{v}$ postižené oblasti.

Důkazy o tom, že lze medikamentózně ovlivnit kritickou perfuzní poruchu dolních končetin jsou slabé a nekonsistentní. Zvláště to platí pro zlepšení ukazatelů, jako je počet amputací a přežívání bez amputace.

Naděje byly $\mathrm{v}$ tomto smyslu vkládány do skupiny prostanoidů, které svým účinkem postihují řadu patofyziologických pochodů, uplatňujících se v přítomnosti kritické ischemie. Vykazují účinek vasodilatační a endoteliálně protektivní, potlačují aktivaci trombocytů a leukocytů, zlepšují erytrocytární deformabilitu a zvýšují fibrinolytickou aktivitu. Zlepšení reologických vlastností krve by se mohlo uplatnit hlavně na úrovni mikrocirkulace za stavů se zpomaleným krevním prouděním a při zánětlivých komplikacích. Klinický zájem se týká hlavně prostaglandinu $\mathrm{E}_{1}\left(\mathrm{PGE}_{1}\right)$ a prostacyklinu s jeho analogy (iloprost, beraprost). Některé studie $s \mathrm{PGE}_{1}$ prokázaly zmenšení vředů a snížení intenzity klidových bolestí, popř. prodloužení klaudikačního intervalu. ${ }^{(62)}$ Jindy byl prokazován pozitivní účinek v hospitalizační době, avšak po šesti měsících již nebyl patrný rozdíl ve srovnání se skupinou s placebem v mortalitě a počtu amputací. ${ }^{(63)}$ Někdy se uvádí zlepšení u nemocných s hraniční úrovní perfuze, kteří přežívají bez amputace; další studie z poslední doby žádný účinek neprokázaly. Dlouhodobá léčba prostanoidy je opodstaněná jen tehdy, když lze pozorovat příznivý účinek (ústup klidových bolestí, tvorba granulační tkáně v oblasti tkáňových defektů, prodloužení klaudikační vzdálenosti apod.). K takovému posouzení je zpravidla potřeba několika týdnů. Jasné důkazy o tom, že by byla jiná farmakoterapie v léčbě chronické kritické ischemie př́nosná, nejsou. ${ }^{(45,56)}$

Zhojení trofického defektu závisí na perfuzi jeho marginálních oblastí, kde začíná tvorba nové tkáně. ${ }^{(64)} U$ řady nemocných dochází ke zlepšení prokrvení svěšením končetiny. Vhodné je omezení fyzické zátěže a chůze, při které mají nízké distální tlaky tendenci poklesnout.

Bakteriální infekce nebývá primárním původcem defektu, ale může být nejdůležitější příčinou, proč se kožní defekt rozšiřuje a nehojí. V nepř́íznivých př́ípadech může infekce destruovat tkáň nohy během 24-48 hodin. Při porušení integrity tkáně není sepse vzácností, ale bývá dlouho latentní. Infekce je problémem zvláště u diabetiků, jejichž obranyschopnost je snížena.

Infekce se udržuje na krajích defektu, zatímco střed propadá nekróze, a je zde tendence k retenci hnisu a sekretů. Zvláštní pozornost je třeba věnovat otevření nekróz a jejich odstranění. Je však nutná opatrnost, aby nedošlo k poškození živé tkáně a dalšímu šíření infekce. Je-li odstranění obtížné, je možné nekrotickou tkáň nejprve změkčit koupelí ve vlažné vodě či mastí. Přehnané zvlhčování však vede k maceraci do té doby nepostižené tkáně a zvýšené náchylnosti k infekci. K čištění defektu je možno využít enzymatických, lokálních př́pravků či aplikaci hyperosmolárních roztoků. Granulační tkáň nemá zaschnout (vhodné překrytí mastí). Je-li třeba podat antibiotika, pak je aplikujeme systémově. Vzhledem k téměř vždy př́tomným anaerobním mikrobům $\mathrm{v}$ defektu, doporučuje se rutinně podávat metronidazol. $\mathrm{Z}$ aerobních bakterií jsou nejčastěji přítomny streptokoky skupiny B a zlatý stafylokok. Proto se léčba zaměřuje na podání antibiotik proti grampozitivům. Špatným znamením je přestup infekce na kostní tkáň

Edém v oblasti defektu zhoršuje hojení. Jeho původ obvykle spočívá v zánětu, zvýšené kapilární propustnosti a častém svěšování ischemické končetiny. Zde lze využít antiedematózního účinku bioflavonoidů. Abychom otok př́znivě ovlivnili, je někdy nutné držet končetinu $\mathrm{v}$ horizontální poloze. To může vyžadovat zavedení či zintenzivnění analgetické léčby. Někdy je nutné provádět peridurální blokádu a analgetika aplikovat zavedeným katetrem.

Hypoxická tkáň je zvýšeně náchylná k tvorbě otlaků a rozvoji dalších defektů. Proto je třeba končetinu polohovat a podkládat. Léčba a prevence interdigitální mykózy jsou pravidelnou nutností.

Je důležité, aby byl nemocný s ischemickou chorobou dolních končetin poučen o nutnosti prevence otlaků, poranění a prochlazení. Musí věnovat dostatečnou pozornost výběru obuvi, hygieně nohou s koupelemi ve vlažné vodě, častým kontrolám stavu kůže, povrchové ochraně míst se zvýšeným třením.

Dnes existuje celá řada firemních programů a výrobků, které se zaměřují na lokální léčbu různých stadií defektů.

Existují i metody, pro které nebyl pozitivní léčebný účinek spolehlivě a dostatečně prokázán. Týká se to např̀ hemodiluční terapie a tlakové kompresivní a imunomodulační terapie. U nemocných s chronickou kritickou ischemií a ischemickými vředy, kteří nemohou být léčeni chirurgicky či endovaskulárně, lze zvážit hyperbarickou oxygenoterapii nebo míšní stimulaci. ${ }^{(56)}$

Ležící a málo pohybliví nemocní s kritickou ischemií dolních končetin mají vyšší výskyt tromboembolické nemoci a vyžadují rutinní prevenci podáváním subkutánního heparinu, není-li kontraindikace.

Analgetika jsou využívána k tlumení klidových bolestí. Je však třeba jasně rozhodnout, zda již byly vyčerpány všechny způsoby účinné léčby kritické ischemie (např. konzultací specializovaného centra), a v případě potřeby provést včas amputaci. Je nesprávné končetinu amputovat až poté, co se nemocný stane závislým na analgetikách.

U akutních tepenných uzávěrů je lékem první pomoci heparin (např. bolus 100 m.j./kg váhy), který má zabránit apozici trombu a prodlužování uzávěru. ${ }^{(65)} \mathrm{S}$ prodlužováním uzávěru se může zhoršit stupeň ischemie a omezit účinnost další léčby. Heparin bývá také rutinně podáván během intervenčních terapeutických výkonů $\mathrm{k}$ prevenci akutní trombózy (v dávce 5-10 tisíc m. j. intraarteriálně). Tam, kde je po výkonu riziko retrombózy zvýšeno (např. po rekanalizaci dlouhých uzávěrů, intervenční léčbě kritické ischemie, po trombolýze), heparinizujeme kontinuálně několik dní, popř. přecházíme na perorální antikoagulancia. Někdy jsou nemocným podávána antiagregancia (i ve formě duální terapie), antikoagulancia i fibrinolytika 
zároveň. Perorální antikoagulaci provádíme dlouhodobě u nemocných po embolizaci do končetinových tepen tam, kde zdroj nebyl nalezen, a tam, kde sice byl objeven, ale nebyl odstraněn.

\section{Indikace a zásady katetrizační a chirurgické léčby}

Při výběru terapeutické metody u nemocných se symptomatickou poruchou perfuze dolních končetin rozhoduje bezpečnost a účinnost léčebné techniky, spolu s předpokladem dlouhodobé průchodnosti. Význam má nejen lokalizace a anatomie postižení spolu s úrovní přítoku a odtoku, ale i klinická závažnost stavu, přítomnost přidružených onemocnění, případně věk. Povšechně řečeno, dlouhodobý účinek reperfuzní léčby se zhoršuje s délkou příčinných tepenných lézí, s počtem postižených segmentů a tepen, při prrítomnosti tkáňových defektů a infekce, při špatné spolupráci nemocného, nedostatečném ovlivnění rizikových faktorů a progresi základního onemocnění.

Konzervativní léčba zpravidla nepřináší potřebný účinek tam, kde je končetina ohrožena (chronická kritická ischemie, závažná akutní ischemie). Zde je třeba vždy fundovaně zvážit možnost endovaskulární či chirurgické intervence.

Na základě existujících dat je zřejmé, že některé typy tepenných lézí je z hlediska dlouhodobé účinnosti vhodnější léčit chirurgicky, jiné endovaskulárně a u dalších lze využít způsoby oba. Technický potenciál pro rekanalizaci a revaskularizaci však není u jmenovaných př́stupů stejný, a tak některé typy postižení lze s výhodou léčit chirurgicky, jiné zase pouze endovaskulárně. Je jen málo př́ípadů, kdy nelze dělat nic. Při zvyšujícím se věku populace stoupá frekvence závažných paralelních onemocnění s vysokým rizikem pro chirurgickou léčbu, a tak jsme často nuceni léčit endovaskulárně, i když dlouhodobý účinek není jistý, a léčbu bude třeba provádět po určité době znovu. Neúspěch intervenční léčby obvykle nezvyšuje riziko ztráty končetiny a negativně neovlivní možnost chirurgického výkonu.

Nejčastějšími intervenčními léčebnými technikami jsou př̀ léčbě chronické formy ischemické choroby dolních končetin perkutánní transluminální angioplastika (PTA) a implantace intravaskulárních stentů (stentgraftů). Vzácně (asi v $1 \%$ prrípadů) jsou využívány i jiné techniky, např. perkutánní aterektomie, pulsní farmakomechanická trombolýza, laserová rekanalizace. Variantami balonkové dilatace jsou subintimální PTA, „cutting balloon” a kryoplastika. Při PTA je do zúženého či uzavřeného cévního úseku zaváděn balonkový katetr přiměřené délky a průměru. Naplněním balonku a jeho expanzí dochází k traumatizaci cévní stěny s rupturou ateromu, jeho částečnému odtržením od cévní stěny a $\mathrm{k}$ různé míře disekce (hluboké trauma). Dále se uplatní roztažení lumen a cévní stěny v místě dilatace spolu s remodelací aterotrombotických hmot. V souvislosti s mírou elasticity tepny $\mathrm{v}$ místě intervence může dojít $\mathrm{v}$ různém časovém odstupu $\mathrm{k}$ retrakci stěny (recoil) a k opětovnému zmenšení lumen. Stenty slouží, po zavedení do cévy, jako kovová endoluminální podpora stěny, která má zabezpečit dostatečně široké cévní lumen a patřičný krevní průtok danou oblastí.

Obecně vzato, $\mathrm{k}$ angiochirurgické léčbě indikujeme nemocné s ohroženou končetinou, kteři mají klidové bolesti, nehojící se infekce, ulcerace či gangrény rychle progredující až $\mathrm{k}$ amputaci. U klaudikantů jsou pak indikací k operaci krátké klaudikace, nález nevhodný pro endovaskulární léčbu či stavy po neúspěšné intervenční terapii. Vzhledem k nízkému riziku jsou indikace k endovaskulární léčbě liberálnější. Mortalita a závažná morbidita jsou při intervenční terapii nízké. Mezi závažné komplikace patři úmrtí (0,2 \%), amputace $(0,2 \%)$ a periferní embolizace (4-5\%). Přibližně 2-3\% nemocných léčených pomocí PTA mají komplikace takového rázu, že vyžadují chirurgické řešení či prodloužení pobytu v nemocnici. ${ }^{(66)}$ Nezávažnými komplikacemi jsou převážně hematomy a falešná aneurysmata v oblasti vpichu (4 \%).

\section{Suprainguinální revaskularizace}

Pomocí balonkové angioplastiky je technický úspěch při léčbě stenóz pánevních tepen vysoký (90-100\%), u dlouhých uzávěrů 80-85\%. Průchodnost po pěti letech je 70-85\%. Výskyt časné restenózy je relativně nízký, kolem $15 \%$. Nejvhodnějším postižením pro endovaskulární léčbu s výborným dlouhodobým účinkem jsou stenózy společné pánevní tepny a krátké stenózy (o délce tř̌i $\mathrm{cm}$ či kratší) zevní pánevní tepny. Velmi dobré výsledky jsou dosahovány i u krátkých stenóz subrenální aorty, uzávěrů a stenóz a. iliaca externa, které se nešiŕí na a. femoralis communis a u jednostranných okluzí a. iliaca communis. ${ }^{(45,56,66)}$

Implantace stentů může prodloužit dlouhodobou průchodnost pánevních tepen, léčených pomocí PTA. Zlepšuje i bezprostřední angiografický účinek.

Významné postižení společných a vnitřních pánevních tepen může vést $\mathrm{u}$ mužů $\mathrm{k}$ projevům vaskulogenní impotence. $\mathrm{V}$ takových př́padech je třeba zkoumat možnosti intervenční léčby, která může mít za příznivých technických podmínek dobrý účinek.

O chirurgické léčbě je třeba na prvním místě uvažovat při uzávěrech subrenální aorty přecházejících na pánevní tepny, difuzních postiženích aorty a pánevních tepen, oboustranných uzávěrech a. iliaca externa, okluzi zahrnující společnou i zevní pánevní tepnu a společnou stehenní tepnu. Využívá se řada typů přemostění pomocí extraanatomických, laparoskopických bypassů a přímých rekonstrukcí. Vzácně se využívá aortoilické endarterektomie. Pro elektivní léčbu aortobifemorálním bypassem se udává perioperační mortalita 1-4\%, po pěti letech je průchodnost u přežívajících nemocných zjištována $v$ 85-90 \% a po deseti letech v 70-75\% případů. ${ }^{(67)}$ Při věku $>75$ let stoupá perioperační mortalita $\mathrm{k} 15 \%{ }^{(68)}$ Menší perioperační riziko, ale i horší dlouhodobá průchodnost, se vyskytují při extraanatomických bypassech (femoro-femorální, axilo-femorální, thorako-femorální).

\section{Infrainguinální revaskularizace}

Endovaskulární léčba postižení femoro-popliteálního segmentu má optimální účinek u izolovaných stenóz dlouhých 
do $10 \mathrm{~cm}$ a uzávěrů nepřesahujících $5 \mathrm{~cm}$. Dobrý účinek lze dále očekávat i u mnohočetných stenóz a uzávěrů, $z$ nichž žádná léze nepřesahuje délku $5 \mathrm{~cm}$. To platí i u delších lézí nezasahujících podkolenní úsek a. poplitea, izolované stenózy podkolenní tepny a při snaze zlepšit př́itok do distálního bypassu v situaci, kdy jsou zavřeny všechny bércové tepny. Naopak špatný výsledek je pravděpodobný u uzávěrů dlouhých (přes $15 \mathrm{~cm}$ ) a zahrnujících podkolenní tepnu, při uzávěru a. poplitea a trifurkace.

Studie věnující se dlouhodobé průchodnosti po intervenční a chirurgické léčbě obvykle ukazují na horší účinek intervencí, kde je za rok průchodná asi polovina tepen a k časné restenóze dochází až ve $40 \%$. Existuje však málo studií, které přímo srovnávají intervenční a chirurgickou léčbu. ${ }^{(69,70)} \mathrm{V}$ nich je dlouhodobá účinnost (4 roky) u klaudikantů kolem $60 \%$ a srovnatelná s chirurgickými metodami. Faktorem, který se negativně uplatňuje, je špatný stav výtokového traktu (bércové tepny) a prrítomnost diabetes mellitus. ${ }^{(71)}$ Lepší výsledky lze očekávat u klaudikujících ve srovnání s chronickou kritickou ischemií.

Technický úspěch je prokazován v 70-97 \%, u stenóz jsou výsledky lepší. Příznivějšího účinku než u samotné PTA je někdy dosahováno použitím samoexpandibilních, nitinolových stentů, ${ }^{(72)}$ zvláště u dlouhých lézí a chronické kritické ischemie. Podobně se mohou uplatnit i stentgrafty ${ }^{(73)}$ zlepšením dlouhodobé průchodnosti. Izolovaný chronický uzávěr či stenóza povrchové stehenní tepny při průchodné hluboké stehenní arterii, a alespoň dvou bércových tepnách, jsou zpravidla provázeny klaudikacemi, a nikoli projevy kritické ischemie s nutností intervence. Téměř všichni nemocní s postižením arteria femoralis superficialis, u kterých je prováděna endovaskulární terapie, mají v různé míře poškozeny bércové tepny, jsou starší s vážnými komorbiditami. Zde léčíme primárně katetrizačními technikami, i když charakter samotného postižení povrchní stehenní tepny by upřednostňoval chirurgický přístup.

Zvláštní pozornost zasluhuje stav hluboké stehenní tepny při významném ipsilaterálním postižení arteria femoralis superficialis. Jsou-li současně významně postiženy obě stehenní tepny, umožní zprůchodnění a. profunda femoris vytvoření kolaterálního oběhu a zlepšení klinické symptomatiky. Plné rozvinutí kolaterálního oběhu lze očekávat až za několik týdnů po úspěšném výkonu.

Intervenční terapie se uplatní i při léčbě restenóz či aneurysmat vzniklých po chirurgických rekonstrukcích.

Infrapopliteální intervence jsou obvykle spojeny se snahou o záchranu končetiny a jsou prováděny stále častěji. Technický úspěch je i zde lepší u krátkých stenóz, než u dlouhých uzávěrů, a pohybuje se mezi 65-96 \% podle typu léze.

Chronická kritická ischemie má téměř vždy příčinu v multisegmentálním postižení a při léčbě je třeba docílit přímého toku do periferie bércových tepen. Intervenční terapie má většinou lepší možnosti na úrovni bérců než chirurgické řešení a má také potenciál provést rekanalizaci více segmentů v jedné době. Úspěšné řešení ve složitých případech však bývá velmi nákladné a dlouhodobý účinek nelze odhadnout. Výkony na bérci jsou bezpečné a obvyklou komplikací (téměř vždy klinicky nevýznamnou) je perforace tepny vodičem či disekce při pokusech o proniknutí uzávěrem do periferního pahýlu. V 65-83\% se udává zachování končetiny po dvou letech. ${ }^{(74)}$ Výkony na bérci jsou často provázeny arteriálními spasmy při mechanickém dráždění tepny, a proto bývá vhodná medikamentózní prevence (např. nitráty).

Význam trombolýzy v léčbě chronických uzávěrů je malý a rutinně se neprovádí. Při pulsní farmakomechanické trombolýze ${ }^{(75)}$ lze dosáhnout rekanalizace přibližně v $80 \%$ a téměř vždy dojde $\mathrm{k}$ rozpuštění alespoň části uzávěru. Problémem však zůstávají nepravidelná rezidua původního uzávěru významně zužující lumen i po skončení aplikace trombolytika. ${ }^{(76)}$ Při PTA pak dochází ve $25 \%$ prrípadů k uvolnění zbytků uzávěrových hmot a k periferní embolizaci.

K chirurgické léčbě přistupujeme při závažné symptomatice, ve snaze o zlepšení prognózy končetiny. Léčebné možnosti jsou ovlivněny hlavně stavem bércového řečiště. S poklesem množství průchodných bécových tepen se zhoršují i výsledky rekonstrukčních operací. Jako doplňující indikační kritéria bývají udávány kotníkové tlaky $<50 \mathrm{~mm} \mathrm{Hg}$ a tlakový dopplerovský index „kotník-paže“ 0,5 a méně. ${ }^{(77)}$ Většinou se provádějí femoropopliteální a femoro-krurální bypassy s použitím autologní žíly. Při použití protézy a heterologní žíly jsou výsledky horší. Perioperační mortalita je při provádění femoro-krurálních bypassů pro osoby mladší 75 let přibližně $2 \%$, u starších nemocných téměř 7\%. ${ }^{(68)}$ Přibližně 6,5 \% nemocných prodělá amputaci po dříve provedené rekonstrukci. Průchodnost femoro-popliteálních bypassů při použití autologní žíly činí po jednom roce $70 \%$, po pěti letech $52 \%$. ${ }^{(78)}$

Rekonstrukční operace se nedoporučuje provádět při afunkční končetině (neurologické postižení, nehybní nemocní). Zde je třeba uvažovat o primární amputaci. U dialyzovaných diabetiků s rozsáhlými gangrénami a nehojícími se vředy nohy je i při průchodném bypassu pravděpodobnost zhojení defektů malá. Nikdo z nich nepřežije 3-5 let. Proto i zde je třeba pečlivě zvažovat provedení rekonstrukce.

Chirurgická a chemická sympatektomie může mít účinek jen u nemocných, kde se uplatňuje sympatikotonus. K jeho průkazu je vhodná zkouška reflexní vasodilatací. Lumbální sympatektomie se nedoporučuje u diabetiků, protože vesměs trpí neuropatií.

$\mathrm{V}$ řadě př́padů je riziko chirurgické léčby zvýšeno. Jedná se hlavně o nemocné se závažným přidruženým onemocněním, jako např. plicní choroby, diabetes mellitus (zvláště při inzulinoterapii), renální insuficience, anemie, polycytemie a trombocytóza. Zvláště významná je př́ítomnost srdečního postižení - ischemická choroba srdeční, kongestivní srdeční insuficience, závažné arytmie, dále cerebrovaskulární onemocnění a nutnost rizikových chirurgických výkonů v anamnéze (např. léčba aortálního aneurysmatu, jiná cévní, hrudní, břišní či ortopedická chirurgie), vyšší věk - přes 70 let. ${ }^{(79)}$ Mortalita a morbidita je nižší u elektivních cévně-chirurgických výkonů ve stro- 
vnání s léčbou emergentní. Vaskulární chirurgické výkony jsou provázeny relativně vyšším rizikem srdečních komplikací než jiné typy operací. Je to vysvětlováno vyšším výskytem koronární nemoci, kolísáním objemu extra- i intravaskulární tekutiny se změnou plnicích tlaků, změnami srdeční frekvence a krevního tlaku.

Endovaskulární terapie je provázena nižší perioperační mortalitou a morbiditou. Po několika letech však mohou být tyto parametry podobné pro oba typy léčby. Důvodem je prrítomnost paralelního závažného postižení koronárního a cerebrovaskulárního řečiště, jejichž prognostický dopad je rozhodující. Proto je třeba po těchto postiženích aktivně pátrat, nebot výrazná symptomatika a limitace z poruchy perfuze dolních končetin zasouvá do pozadí příznaky $\mathrm{z}$ poruch $\mathrm{v}$ jiné regionální cirkulaci. Pacient může mít prospěch z provedení koronární a karotické revaskularizace $\mathrm{v}$ době před rizikovým cévně-chirurgickým výkonem $\mathrm{v}$ jiné lokalizaci.

\section{Léčba akutní ischemie dolních končetin}

Nejpopulárnějšími metodami v léčbě akutní ischemie dolních končetin jsou trombolýza a chirurgické řešení.

Chirurgická léčba akutních uzávěrů je obvykle prováděna pomocí Fogartyho embolektomie u embolií a přemostovací operací u trombóz. Téměř vždy bývá léčebnou metodou první volby u nemocných s uzávěry aortoilického segmentu vzhledem k možnosti rychlé reperfuze. Historické výsledky se pohybují ve značném rozmezí: periprocedurální mortalita 7-35\%, amputace 5-48\% se záchranou končetiny v 75-100 \% př́padů. V randomizovaných studiích, kde byla porovnávána chirurgická léčba s trombolýzou, činila chirurgická periprocedurální mortalita 4-18\%. Za rok po léčbě žilo s oběma končetinami 52-82\% nemocných. ${ }^{(80-83)}$ Rozdíly mezi oběma přístupy v perioperační mortalitě, závažné morbiditě a účinnosti nejsou považovány, až na výjimky, za významné.

Mortalita je v chirurgických souborech ovlivněna přítomností chronického srdečního onemocnění, kardiopulmonálními komplikacemi, infarktem myokardu, věkem a je horší u nemocných s hyperakutním průběhem, kteří se musejí dostat na sál bez př́pravy, rovnou z ulice. Trombolytická léčba je sice méně invazivní, avšak ohrožující komplikace zde představuje krvácení.

Při uzávěrech v oblasti trifurkace a dlouhých uzávěrech bércových tepen jsou možnosti chirurgické léčby omezeny. Čím je delší období závažné akutní poruchy perfuze, tím je pravděpodobnější výskyt reperfuzních komplikací.

Při perkutánním prrístupu se využívají a kombinují hlavně metody snažící se odstranit krevní sraženinu z tepny (perkutánní tromboembolektomie) s technikami, které sraženinu rozpouštějí (farmakologická trombolýza) či rozrušují (mechanická trombolýza). Výhodou intervenční léčby se zdá možnost ovlivnit př́ćčinnou lézi ihned po odstranění uzávěrových hmot, a tak vytvořit podmínky pro dlouhodobý účinek léčby.

Perkutánní aspirační tromboembolektomie ${ }^{(84)}$ lze využít u akutních uzávěrů tepenného řečiště periferně od třísla, a zvláště v oblasti podkolenní tepny a tepen bércových. Jde se o relativně účinnou metodu, bez významnějších komplikací a kontraindikací. U embolií i trombóz je její úspěšnost kolem 70 \%. Metoda je založena na zavedení katetru z tř́sla $\mathrm{k}$ uzávěru a nasátí či přisátí uzávěrových hmot a jejich odstranění. Účinnost je limitována přítomností rigidní a objemné částice krevní sraženiny, jejím nepravidelným tvarem, obtížnou dostupností pro katetr, spasmem tepny a pokračující trombózou.

Ve snaze zachovat malou invazivitu katetrizační léčby a eliminovat krvácení při farmakologické trombolýze, jsou vyvíjeny i další mechanické techniky. Jejich využití je však doposud limitováno možností poranění cévní stěny, periferní embolizací, nedokonalým odstraněním sraženiny, s nutností následné farmakologické trombolýzy a omezeným využitím v tepnách malého průměru (bérec).

Při lokální kontinuální trombolýze zavádíme katetr $s$ řadou bočních otvorů přímo do uzávěru. U krátkých uzávěrů $(<5 \mathrm{~cm})$ používáme katetr s jedním otvorem na konci. Nemocný pak opouští katetrizační sál a s pomocí infuzní pumpy je do uzávěru přiváděno trombolytikum ${ }^{(85)}$ dnes využíváme výhradně př́mých aktivátorů plasminogenu pro vyšší účinnost a menší výskyt komplikací (u nás obvykle altepláza). Léčba probíhá na jednotce intenzivní péče. V pravidelných intervalech (zpravidla 6-12 hodin) se provádí angiografická kontrola a trombolýza je ukončena při rozpuštění uzávěru nebo v případě, že se nedostavil žádný účinek. Alteplázu aplikujeme nejčastěji v dávce $1 \mathrm{mg} / \mathrm{h}$. Léčba trvá typicky 24-48 hodin. Tento způsob podání ovlivňuje koagulační časy a koncentraci fibrinogenu minimálně, proto je třeba současně aplikovat infuzi s heparinem $\mathrm{k}$ prevenci perikatetrové trombózy. Rychlost této infuze se řídí snahou o dvojnásobné až trojnásobné prodloužení aktivovaného parciálního tromboplastinového času (APTT). Rutinně provádíme každých šest hodin kontrolu krevního obrazu a trombocytů, trombinového času, APTT a fibrinogenu. Na místě je preventivní zajištění kompatibilní krve do rezervy. Primární účinnost u akutních uzávěrů se pohybuje v rozmezí $59-100 \%{ }^{(86)}$ a významná šance na úspěch je i u uzávěrů subakutních (do tři měsíců trvání). Závažné komplikující krvácení je popisováno v rozmezí 0-35 \%, intrakraniální krvácení u 0-9 \% pacientů. Výhodou kontinuální lokální trombolýzy je rozpuštění prakticky veškeré sraženiny bez reziduálních zbytků na stěnách tepen.

Kontraindikací trombolytické léčby je probíhající krvácení, prrítomnost mozkového tumoru, stav po kraniotomii do dvou měsíců a období bezprostředně po porodu. Obecně je však třeba říci, že podání fibrinolytik představuje léčebnou proceduru, kterou nemá lékař nikdy zcela pod kontrolou. K život ohrožujícímu krvácení může dojít i u nemocných, kde riziko není předem zjevné. Je proto plně na lékaři, který léčbu indikuje, aby individuálně zvážil možný prrínos ve vztahu k riziku; zkušenost s tímto typem terapie je nutná, nebot' relativních kontraindikací existuje značné množství. Plná informovanost pacienta o závažnosti zdravotního stavu, možných léčebných postupech a komplikacích i jeho souhlas s léčbou, jsou též nezbytné. 


\section{Reperfuzní poškození}

Při obnovení krevního toku ischemickým svalem dochází $\mathrm{k}$ vyplavení iontů, proteinů a enzymů $\mathrm{z}$ porušených buněk do systémové cirkulace. Myoglobinemie, myoglobinurie, laktacidóza a hyperkalemie mohou vést $\mathrm{k}$ projevům akutní renální insuficience, hemodynamické nestability, poruchám srdečního rytmu a kontraktility myokardu. Následkem poruchy buněčných membrán, nitrobuněčných organel a insuficience ATPázy, vázané na membránu, vzniká intracelulární edém. Zvýšení kapilární (mikrocirkulační) permeability vede $\mathrm{k}$ edému intersticiálnímu. Rozsah otoku a jeho intenzita závisí na době trvání ischemie, objemu poškozené tkáně a na úrovni revaskularizace. $\mathrm{S}$ progresí otoku v prostoru uzavřeného osteofasciálního kompartmentu se zde zvyšuje intersticiální tlak (kompartmentový syndrom). Při jeho vzestupu $>30 \mathrm{~mm} \mathrm{Hg}$ (kapilární perfuzní tlak), dojde $k$ poruše perfuze a tkáňové ischemii, i když byla revaskularizace úspěšná. Léčebným řešením je včas provedená fasciotomie.

Příčinou obstrukce krevního proudu na úrovni mikrocirkulace může být i edém samotných endoteliálních buněk, provázený přítomností shlukủ bílých krvinek a krevních destiček. Dlouhodobá stáza krve a poškození endoteliálních buněk vedou $\mathrm{k}$ trombóze malých cév na arteriální i žilní straně. Masivní vyplavení mikrotrombů z žilní části cévního řečiště tkáně, postižené ischemií, může mít za následek obstrukci drobných plicních arterií a závažnou poruchu plicní funkce.

Stupeň konečného poškození je určen nejen účinkem ischemie a hypoperfuze, ale i neprŕíznivým vlivem reperfuze po úspěšné rekanalizaci. Jako př́čina negativního účinku obnovy krevního průtoku je uváděn vznik volných kyslíkových radikálů, poškozujících membrány buněk a organel. Uplatňuje se i aktivace neutrofilů, infiltrujících svalovou tkáň, s uvolněním lysozymů a rozpadem nebuněčné i buněčné (zdravé) tkáně.

$\mathrm{Z}$ uvedeného je zřejmé, že $\mathrm{k}$ ireverzibilnímu poškození vede akutní ischemie dlouhotrvající, při které je také reperfuzní trauma výraznější. Může $\mathrm{k}$ němu však dojít i po revaskularizaci u nemocných s chronickou kritickou ischemií.

Reperfuzní syndrom se vyskytuje u nemocných, operovaných pro akutní ischemii dolních končetin, v 7,5-15\%; asi $9 \%$ nemocných po emergentní revaskularizaci vyžaduje fasciotomii.

\section{Obecné principy péče o nemocné s postižením tepen dolních končetin}

$\mathrm{Z}$ důvodů závažné prognózy, sociálních dopadů a ekonomické náročnosti je třeba věnovat pozornost hlavně nemocným s akutními tepennými uzávěry a chronickou kritickou ischemií. Péče o tyto nemocné patří do rukou zkušeného týmu, který je v první řadě schopen zabezpečit kvalitní diagnostiku s následnou odpovídající intervenční a angiochirurgickou léčbou (intervenční angiolog či radiolog a angiochirurg). Pouze na pracovišti, které o uvedené ne- mocné pečuje rutinně a ve velkém počtu, má nemocný největší šanci, že bude zvolen optimální způsob okamžité léčby a bude zabezpečen i její dlouhodobý účinek. To vše za přiměřených nákladů.

Péče o cévní pacienty je však komplexní a účastní se jí celá řada dalších profesí (kardiolog, neurolog, diabetolog, hematolog, revmatolog a další). Z toho důvodu dochází ve světě $k$ organizaci tzv. vaskulárních center, účinně zajištujících komplexní klinickou péči, vzdělávací i výzkumné programy. ${ }^{(87)}$

U akutních tepenných uzávěrů se zdá být největším problémem to, že řada nemocných nemá správně provedenu diagnózu lékařem prvního kontaktu, nemocný je ponechán v ambulantní péči a až po čase, při zhoršování stavu, je odeslán ke specializované léčbě. Po několika týdnech je účinnost léčby snížena, na což doplatí hlavně nemocní $s$ nejzávažnějším postižením. O léčbu akutních uzávěrů periferních tepen se v minulosti staral výhradně chirurg, lékař s klinickou erudicí, která je třeba k posouzení rizika a možného prospěchu různých způsobů léčby. $V$ dnešní době se stále více prosazuje intervenční léčba, která může pomoci nemocným i tam, kde chirurgická léčba není možná. Je třeba se vyvarovat situací, kdy po zjištění, že chirurgická léčba není možná, nedojde k fundovanému posouzení možností intervenčních postupů. Obecně vzato, při akutních uzávěrech suprainguinálně dáváme přednost terapii chirurgické a při infraiguinálních okluzích léčbě intervenční.

Postižení chronickou kritickou ischemií a netraumatická amputace dolních končetin se týkají hlavně pacientů s diabetes mellitus. Kromě obecně vyšší tendence $\mathrm{k}$ vzniku aterosklerózy v jiných oblastech, tito nemocní mají častěji postižené bércové tepny, většinou jako součást multisegmentální tepenné poruchy. Obvykle přicházejí $\mathrm{k}$ angiologické léčbě až $s$ tkáňovými defekty, zánětem a klidovými bolestmi bez předchozího, dobře definovaného klaudikačního stadia. Anatomie postižení je v té době již rozsáhlá a komplikovaná, s omezenými možnostmi revaskularizace. U diabetiků je třeba více než u jiných skupin pacientů detekovat perfuzní poruchy sledováním a měřením vhodných fyziologických parametrů, jako např. prstové tlaky, neinvazivní stanovení průtoku, ultrazvukové vyšetření, časy polohového testu. Diabetologické poradny sehrávají důležitou roli při časném vyhledávání příznaků periferní tepenné nemoci a iniciování specializovaných vyšetření. Nemocní $s$ chronickou kritickou ischemií a také ti, kteří se tomuto stavu přibližují, patří do komplexní péče specializovaného pracoviště.

Onemocnění periferních tepen je důležitým markerem signalizujícím zvýšené riziko pro postižení jiných oblastí, které dominantně určují mortalitu a závažnou morbiditu (koronární a cerebrovaskulární oblast, břišní aorta, renální tepny). Angiolog musí aktivně příznaky z postižení uvedených oblastí vyhledávat a zabezpečit potřebná doplňující odborná vyšetření.

Je doporučováno, aby každému s věkem nad 50 let byl stanoven tlakový index „kotník-paže“ a posouzena př́tom- 
nost asymptomatické tepenné poruchy. Při normálním nálezu je vhodné provádět alespoň jednou za jeden až dva roky kontrolní vyšetření.

Do budoucna se pro zabezpečení adekvátní péče o nemocné s postižením periferních tepen jeví jako nezbytné podpořit aktivity, vedoucí ke zlepšení erudice v oblasti cévních onemocnění u lékařů prvního kontaktu. Neméně důležité je vytvoření funkčního spojení a spolupráce mezi těmito lékaři a vaskulárním centrem. Vyloučí se tak zdlouhavé cestování nemocného od jednoho lékaře ke druhému, z jedné nemocnice do druhé, opakované vyšetřování bez provedení potřebných rozhodnutí a čekání na hospitalizaci.

\section{Literatura}

1. Fowkes FG, Housley E, Riemersma RA, et al. Smoking, lipids, glucose intolerance, and blood pressure as risk factors for peripheral atherosclerosis compared with ischemic heart disease in the Edinburgh Artery Study. Am J Epidemiol 1992;135:331-40.

2. Price JF, Mowbray PI, Lee AJ, et al. Relationship between smoking and cardiovascular risk factors in the development of peripheral arterial disease and coronary artery disease: Edinburgh Artery Study. Eur Heart J 1999; 20:344-53.

3. Criqui MH, Denenberg JO, Langer RD, et al. The epidemiology of peripheral arterial disease: importance of identifying the population at risk. Vasc Med 1997;2:221-6.

4. Hiatt WR, Hoag S, Hamman RF. Effect of diagnostic criteria on the prevalence of peripheral arterial disease. The San Luis Valley Diabetes Study. Circulation 1995:91:1472-9.

5. Pomrehn P, Duncan B, Weissfeld L, et al. The association of dyslipoproteinemia with symptoms and signs of peripheral arterial disease. The Lipid Research Clinics Program Prevalence Study. Circulation 1986;73 (Suppl):1100-I107.

6. Graham IM, Daly LE, Refsum HM, et al. Plasma homocysteine as a risk factor for vascular disease. The European Concerted Action Project. JAMA 1997; 277:1775-81.

7. Ridker PM, Stampfer MJ, Rifai N. Novel risk factors for systemic atherosclerosis: a comparison of C-reactive protein, fibrinogen, homocysteine, lipoprotein(a), and standard cholesterol screening as predictors of peripheral arterial disease. JAMA 2001;285:2481-5.

8. Kullo IJ, Bailey KR, Kardia SL, et al. Ethnic differences in peripheral arterial disease in the NHLBI Genetic Epidemiology Network of Arteriopathy (GENOA) study. Vasc Med 2003;8:237-42.

9. Resnick HE, Lindsay RS, McDermott MM, et al. Relationship of High and Low Ankle Brachial Index to All-Cause and Cardiovascular Disease Mortality: The Strong Heart Study. Circulation 2004;109;733-9.

10. Criqui MH, Fronek A, Barrett-Connor E, et al. The prevalence of peripheral arterial disease in a defined population. Circulation 1985;71:510-5.

11. Kannel WB, Skinner JJ Jr, Schwartz MJ, Shurtleff D. Intermittent claudication: incidence in the Framingham study. Circulation 1970;41:875-83.

12. Dormandy J, Mahir M, Ascady G, et al. Fate of the patient with chronic leg ischemia. J Cardiovasc Surg 1989;30:50-7.

13. Hertzer NR. The natural history of peripheral vascular disease. Circulation 1991;83 (Suppl I):I-12-I-19.

14. European working group on critical leg ischemia. Second European consensus document on chronic critical leg ischemia. Circulation 1991;84 (Suppl IV)1-26.

15. Strandness Jr DE. Atherosclerosis in diabetes. J Vasc Invest 1995;1:50-4.

16. Salmasi A-M, Nicolaides A, Al-Katoubi, A et al. Intermittent claudication as a manifestation of silent myocardial ischemia: a pilot study. J Vasc Surg 1991;14:76-86.

17. Wolfe JHN. Defining the outcome of critical ischemia: a one year prospective study. Br J Surg 1986;73:321.

18. Pell JP, Fowkes FGR. Epidemiology of critical limb ischemia. Critical Ischaemia 1992;2:22-9.

19. Fontaine R, Kirn M, Kieny R. Die chirurgische Behandlung der peripheren Durchblutungsstörungen. Helv Chir Acta 1954;5/6:499-533.

20. Rutherford RB. Standards for evaluating results of interventional therapy for peripheral vascular disease. Circulation 1991;83 (Suppl I):I 6-I 11.
21. Rutherford RB, Becker GJ. Standards for evaluating and reporting the results of surgical and percutaneous therapy for peripheral arterial disease. JVasc Interv Radiol 1991;2:169-74.

22. Consensus Document. Circulation 1991;84 (Suppl IV):1-26.

23. Bulvas M, Sommerová Z, Urbanová R. Blue toe syndrome - příznak modrého prstu. V: Angiologie 2006 - Trendy soudobé angiologie. Red. K. Roztočil. Praha: Galén, 2006.

24. Přerovský I. Ischemická choroba dolních končetin (ICHDK). Cor Vasa 1993; 35:K55-K61.

25. Linhart J, Dejdar R, Přerovský I, Hlavová A. Spolehlivost fyzikální diagnostiky tepenných uzávěrů na dolních končetinách. Čas Lék čes 1970;119: 956-60.

26. Carter SA. Clinical measurements of systolic pressures in limbs with arterial occlusive disease. J Am Med Assoc 1969;207:1869-74.

27. Fronek A. Noninvasive diagnostics in vascular disease. New York: McGraw-Hill Book Company, 1989.

28. Raines JK, Darling RG, Buth J, et al. Vascular laboratory criteria for the management of peripheral vascular disease of the lower extremities. Surgery 1976;79:21-9.

29. Taguchi JT, Suwangool P. Pipe-stem brachial arteries: a cause of pseudohypertension. J Am Med Assoc 1974;228:733.

30. Franzeck UK, Bernstein EF, Fronek A. The effect of sensing site on the limb segmental blood pressure determination. Arch Surg 1981;116:912-6.

31. Sumner DS. Volume plethysmography in vascular disease: an overview. In: noninvasive diagnostic techniques in vascular disease. Ed. Bernstein EF. St. Louis: Mosby, 1985.

32. Winsor T. Influence of arterial disease on the systolic blood pressure gradients of the extremity. Am J Med Sci 1950;220:117-26.

33. Whitney RJ. The measurement of volume changes in human limbs. J Physiol 1953;121:1-7.

34. Hertzman AB. Photoelectric plethysmograph of the skin. In: Methods of Medical Research. Ed. Potter RR. Chicago: Year Book, 1948.

35. Puchmayer $V$, Bartůněk $P$, Bulvas $M$. Klidová a zátěžová oscilografie jako screeningová metoda pro odhalení poruch obvodových tepen. Vnitř Lék 1977;23:1083-96.

36. Kozák P. Registrace pulzu při diagnóze chorob končetinových tepen dvoukanálovým oscilografem k zápisu pulzových objemových změn. Čas Lék čes 1965;104:103-7.

37. Ouriel K, Zarins CK. Doppler ankle pressure: an evaluation of three methods of expression. Arch Surg 1982;117:1297-300.

38. Rose SC. Noninvasive Vascular Laboratory for Evaluation of Peripheral Arterial Occlusive Disease: Part II—Clinical Applications: Chronic, Usually Atherosclerotic, Lower Extremity Ischemia. J Vasc Intervent Radiol 2001;1:1257-75.

39. Wutschert R, Bounameaux H. Determination of amputation levelin ischemic limbs. Reappraisal of the measurement of Tc $\mathrm{PO}_{2}$. Diabetes Care 1997; 20:1315.

40. Eiberg JP, Lundorf E, Thomsen C, Schroeder TV. Peripheral vascular surgery and magnetic resionance arteriography - a review. Eur J Vasc Endovasc Surg 2001;22:396-402.

41. Fleischmann D, Hallett RL, Roubin GD. CT angiography of peripheral arterial disease. J Vasc Interv Radiol 2006;17:3-26.

42. Singh H, Cardella JF, Cole PE, et al. Quality Improvement Guidelines for Diagnostic Arteriography. J Vasc Interv Radiol 2003;14:S283-S288.

43. Speck U. X-ray contrast media. Overview, use and pharmaceutical aspects. Berlin, Heidelberg: Springer Verlag, 1991:1-54.

44. Waybill MM, Waybill PN. Contrast Media-induced Nephrotoxicity: Identification of Patients at Risk and Algorithms for Prevention. J Vasc Interv Radiol 2001;12:3-9.

45. Hirsch AT, Haskal ZJ, Hertzer NR, et al. ACC/AHA 2005 Guidelines for the Management of Patients With Peripheral Arterial Disease (Lower Extremity, Renal, Mesenteric, and Abdominal Aortic): A Collaborative Report from the American Association for Vascular Surgery/Society for Vascular Surgery, Society for Cardiovascular Angiography and Interventions, Society for Vascular Medicine and Biology, Society of Interventional Radiology, and the ACC/AHA Task Force on Practice Guidelines (Writing Committee to Develop Guidelines for the Management of Patients With Peripheral Arterial Disease) Endorsed by the American Association of Cardiovascular and Pulmonary Rehabilitation; National Heart, Lung, and Blood Institute; Society for Vascular Nursing; TransAtlantic Inter-Society Consensus; and Vascular Disease Foundation. J Am Coll Cardiol 2006;47:1239-312. 
46. Králíková E, Býma $S$, Cífková $R$, et al. Doporučení pro léčbu závislosti na tabáku. Čas Lék čes 2005;144:327-33.

47. Smith SC Jr, Allen J, Blair SN, et al. AHA/ACC Guidelines for Secondary Prevention for Patients With Coronary and Other Atherosclerotic Vascular Disease: 2006 Update. Circulation 2006;113:2363-72.

48. Grundy SM, Cleeman Jl, Daniels SR, et al. Diagnosis and Management of the Metabolic Syndrome. Circulation 2005;112:2735-52.

49. Eckel RH, Kahn R, Robertson RM, et al. Preventing Cardiovascular Disease and Diabetes. Circulation 2006;113:2943-6.

50. Daniels SR, Arnett DK, Eckel RH, et al. Overweight in Children and Adolescents. Pathophysiology, Consequences, Prevention, and Treatment. Circulation 2005;111:1999-2012.

51. Rosendorff C, Black HR, Cannon CP, et al. Treatment of hypertension in the prevention and management of ischemic heart disease. Circulation 2007; 115:2761-88.

52. Cífková R, Býma $S$, Češka $R$, et al. Prevence kardiovaskulárních onemocněn $v$ dospělém věku. Společné doporučení českých odborných společností. Vnitř Lék 2005;51:1021-36.

53. Vaverková $H$, Soška V, Rosolová $H$, et al. Doporučení pro diagnostiku a léčbu dyslipidemií v dospělosti, vypracované výborem České společnosti pro aterosklerózu. Cor Vasa 2007;49 (Suppl):47-60.

54. The Task Force on Diabetes and Cardiovascular Diseases of the European Society of Cardiology (ESC) and of the European Association for the Study of Diabetes (EASD). Eur Heart J 2007;28:88-136.

55. Guidelines on diabetes, pre-diabetes, and cardiovascular diseases. Eur Heart J 2007;28:88-136.

56. Norgren L, Hiatt WR, Dormandy JA, et al. Inter-Society Consensus for the Management of Peripheral Arterial Disease (TASC II). Eur J Vasc EndovasC Surg 2007;33 (Suppl 1):S1-S75

57. Izquierdo-Porrera AM, Gardner AW, Powell CC, Katzel LI. Effects of exercise rehabilitation on cardiovascular risk factors in older patients with peripheral arterial occlusive disease. J Vasc Surg 2000;31:670-7.

58. Stoyioglou A, Jaff MR. Medical treatment of peripheral arterial disease: A comprehensive review. J Vasc Interv Radiol 2004;15:1197-207.

59. Accetto B. Beneficial hemorheologic therapy of chronic peripheral arterial disorders with pentoxifylline: results of double-blind study versus vasodilator - nylidrin. Am Heart J 1982;103:864-9.

60. Girolami B, Bernardi E, Prins MH, et al. Treatment of intermittent claudication with physical training, smoking cessation, pentoxifylline, or nafronyl: a meta analysis. Arch Intern Med 1999;159:337-45.

61. Mohler ER 3rd, HiattWR, Creager MA. Cholesterol reduction with atorvastatin improves walking distance in patients with peripheral arterial disease. Circulation 2003;108:1481-6.

62. Diehm C, Balzer K, Bisler $\mathrm{H}$, et al. Efficacy of a new prostaglandin E1 regimen in outpatients with severe intermittent claudication: results of a multicenter placebo-controlled double-blind trial. J Vasc Surg 1997;25:537-44.

63. The ACAl Study Group. Prostanoids for chronic critical leg ischemia: a randomized, controlled open-label trial with prostaglandin E1. Ischemia cronica degli arti inferiori. Ann Intern Med 1999;130:412-21.

64. Schoop W, Schmidtke I. What is meant by conservative therapy for ischaemic lesions? Critical Ischaemia 1991;1:28-31.

65. Hirsh J, Fuster V. Guide to anticoagulant therapy part 1: heparin. Circulation 1994;89:1449-68

66. Pentecost MJ, Criqui MH, Dorros G, et al. Guidelines for Peripheral Percutaneous Transluminal Angioplasty of the Abdominal Aorta and Lower Extremity Vessels A Statement for Health Professionals From a Special Writing Group of the Councils on Cardiovascular Radiology, Arteriosclerosis, Cardio-Thoracic and Vascular Surgery, Clinical Cardiology, and Epidemiology and Prevention, the American Heart Association. J Vasc Interv Radiol 2003;14:S495-S515.

67. Johnston KW. Management of chronic ischemia of the lower extremities. In: Vascular Surgery, Rutherford RB ed. Philadelphia: Elsevier Saunders, 2005:1077-94.
68. Plecah FR, Bernn VJ, Plecha EJ, et al. The early results of vascular surgery in patients 75 years of age and older: an analysis of 3259 cases. J Vasc Surg 1985;2:769-74.

69. Wolf G, Wilson S, Cross A, et al. Surgery or balloon angioplasty for peripheral vascular disease: a randomized clinical trial. J Vasc Interv Radiol 1993;4: 639-48.

70. Adam DJ, Beard JD, Cleveland T, et al. Bypass versus angioplasty in severe ischaemia of the leg (BASIL): multicentre, randomised controlled trial. Lancet 2005;366 (9501):1925-34.

71. Clark TWI, Groffsky JL, Soulen MC. Predictors of long-term patency after femoropopliteal angioplasty: results from the STAR registry. J Vasc Interv Radiol 2001;12:923-33.

72. Schillinger $M$, Sabeti $S$, Loewe $C$, et al. Balloon angioplasty versus implantation of nitinol stents in the superficial femoral artery. N Engl J Med 2006;354:1879-88

73. Saxon RR, Coffman JM, Gooding JM, Natuzzi E, Ponec DJ. Long-term results of ePTFE stent-graft versus angioplasty in the femoropopliteal artery: single center experience from a prospective, randomized trial. J Vasc Interv Radiol 2003;14:303-11.

74. Kandarpa K, Becker GJ, Hunink M, et al. Transcatheter interventions for the treatment of peripheral atherosclerotic lesions: Part I. J Vasc Interv Radiol 2001;12:683-95.

75. Bookstein JJ, Valji K. Pulse-spray pharmacomechanical thrombolysis. Cardiovasc Intervent Radiol 1992;15:228-33.

76. Bulvas M, Urbanová R, Sommerová Z, Chochola M. The role of intravascular stents in preventing peripheral embolization during pulse - spray thrombolysis. Sb. lék. 1995;96:301-8.

77. Mills JL, Bandyk DF. Surgical management of femoropopliteal occlusive disease. In: Vascular diseases. Surgical and interventional therapy. Strandness DE, Van Breda A, eds. New York: Churchill Livingstone, 1994.

78. Veith FJ, Gupta SK, Samson RH, et al. Progress in limb salvage by reconstructive arterial surgery combined with new or improved adjunctive procedures. Ann Surg 1981;194:386.

79. Fleisher LA, Beckman JA, Brown KA, et al. ACC/AHA 2007 Guidelines on perioperative cardiovascular evaluation and care for noncardiac surgery: a report of the American College of Cardiology/American Heart Association Task Force on Practice Guidelines (writing committee to revise the 2002 guidelines on perioperative cardiovascular evaluation for noncardiac surgery): developed in collaboration with the American Society of Echocardiography, American Society of Nuclear Cardiology, Heart Rhythm Society, Society of Cardiovascular Anesthesiologists, Society for Cardiovascular Angiography and Interventions, Society for Vascular Medicine and Biology, and Society for Vascular Surgery. J Am Coll Cardiol 2007;50:e159-e241.

80. Ouriel K, Shortell CK, DeWeese JA, et al. A comparison of thrombolytic therapy with operative revascularization in the initial treatment of acute peripheral arterial ischemia. J Vasc Surg 1994;19:1021-30.

81. Anonymous. Results of a prospective randomized trial evaluating surgery versus thrombolysis for ischemia of the lower extremity. The STILE trial. Ann Surg 1994;220:251-66.

82. Comerota AJ, Weaver FA, Hosking JD, et al. Results of a prospective, randomized trial of surgery versus thrombolysis for occluded lower extremity bypass grafts. Am J Surg 1996;172:105-12.

83. Ouriel K, Veith FJ, Sasahara AA. Thrombolysis or peripheral arterial surgery: phase I results. TOPAS Investigators. J Vasc Surg 1996;23:64-73.

84. Wagner $\mathrm{J}-\mathrm{H}$, Starck EE. Acute embolic occlusions of the infrainguinal arteries: percutaneous aspiration embolectomy in 102 patients. Radiology 1992;182:403-7.

85. Katzen BT. Technique and results of „low dose“ infusion. Cardiovasc Interv Radiol 1988;11:S41-S47.

86. Valji K. Evolving Strategies for Thrombolytic Therapy of Peripheral Vascular Occlusion. J Vasc Interv Radiol 2000;11:411-20.

87. Shepherd JT, Bergan JJ, Cohen RA, et al. Report of the task force on vascular medicine. Circulation 1994:89:532-5. 